Environmental Sciences Division

\title{
BIOACCUMULATION MONITORING AND TOXICITY TESTING IN STREAMS AND GROUNDWATER WELLS AT THE U.S. DEPARTMENT OF ENERGY'S KANSAS CITY PLANT
}

\author{
G. R. Southworth, A. J. Stewart, M. J. Peterson, and T. L. Ashwood
}

Environmental Sciences Division

Publication No. 3758

Manuscript Completed-August 1991

Date Published-March 1992

Prepared for

Allied-Signal Inc., Kansas City Division under Integrated Contractor Order L30527-04

Prepared by the

OAK RIDGE NATIONAL LABORATORY

Oak Ridge, Tennessee 37831 managed by

MARTIN MARIETTA ENERGY SYSTEMS, INC.

for the

U.S. DEPARTMENT OF ENERGY

under contract DE-AC(05-84OR2140) 


\section{CONTENTS}

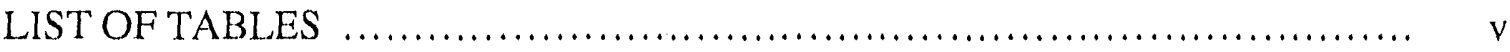

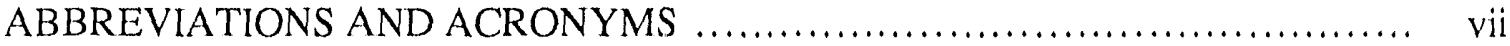

EXECUTIVE SUMMARY …................................................. ix

BIOACCUMULATION MONITORING …............................... ix

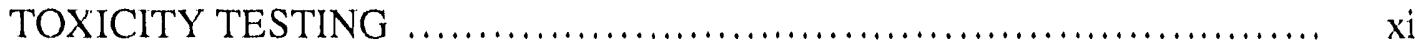

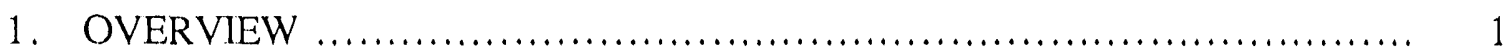

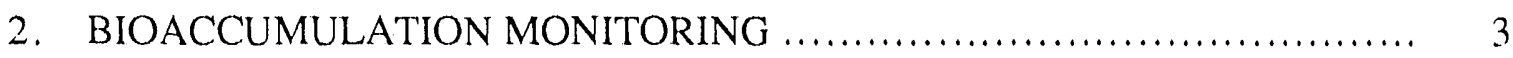

2.1 INTRODUCTION ................................................ 3

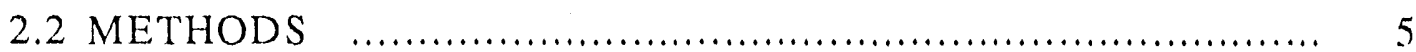

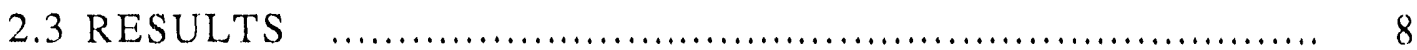

2.3.1 Polychlorinated Biphenyls (PCBs) ................................. 8

2.3.2 Other Contaminants ..................................... 12



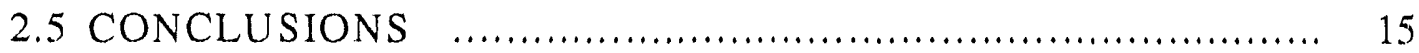

2.5.1 Conclusions Supported by Both Capillary Column and Packed Column Results .................................................... 15

2.5.2 Conclusions Supported by Only One of the Two Datasets ......... 16

2.5.3 Overall Conclusion ....................................... 16

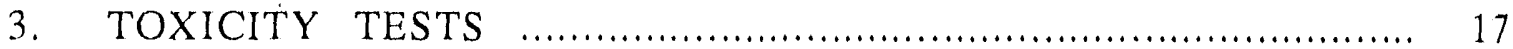

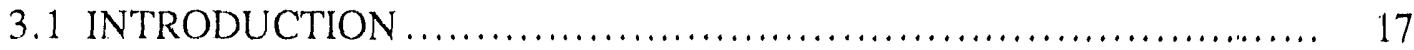

3.2.1 Water Samples ............................................... 17

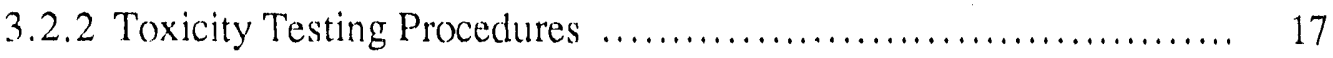

3.2.3 Pure-Chemical Tests ............................................ 18

3.2.4 Statistical Analyses ............................................. 19

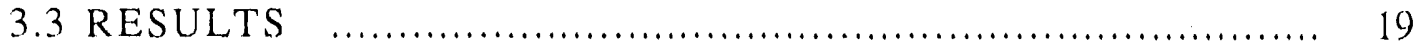

3.3.1 Toxicity Tests ............................................. 19

3.3.2 Chemical Measurements ...................................... 22

3.4 DISCUSSION ............................................... 24



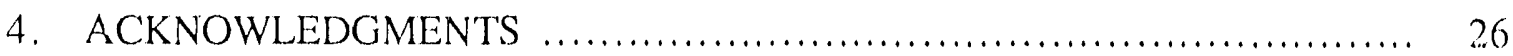

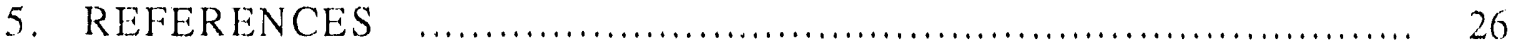


CONTENTS (continued)

Appendix A: QUALITY ASSURANCE DATA $\ldots \ldots \ldots \ldots \ldots \ldots \ldots \ldots \ldots \ldots \ldots$ A-1

Appendix B: DETAILED RESULTS OF PCB ANALYSES ….............. B-1

Appendix C: REPORT OF NEGATIVE ION CHEMICAL IONIZATION MASS SPECTROMETRY OF BLUE RIVER

Appendix D: DETALLS OF METHODS FOR TOXICITY TEST SAMPLE HANDLING

D-1 


\section{LIST OF TABLES}

1 Fish sampling sites in Indian Creek and the Blue River near the Kansas City Plant (KCP)

2 Concentrations of PCBs $(\mu \mathrm{g} / \mathrm{g}$ wet $w \mathrm{t})$ in composite fish samples from streams near the Kansas City Plant

3. Concentrations of PCBs $(\mu \mathrm{g} / \mathrm{g}$ wet weight) in fish samples from streams near the Kansas City Plant, measured by packed column gas chromatography ....

4 Concentrations of pesticides ( $\mu \mathrm{g} / \mathrm{g}$ wet $\mathrm{wt}$ ) in composite fish samples from streams near the Kansas City Plant

5 Volatile organics detected in water samples shipped from the Kansas City Plant to Oak Ridge National Laboratory for toxicity testing

6 Summary of Ceriodaphnia survival and reproductive responses in sealed serum bottles containing control (diluted mineral) water, water from outfall 001, and water from Kansas City Plant wells KC89-105 or KC89-120

7 Summary of Ceriodaphnia survival and reproduction in air-sparged, nondiluted water samples

8 Summary of Ceriodaphnia survival and reproduction in air-sparged, $50 \%$-diluted water samples

9 ANOVA of Ceriodaphnia reproduction in relation to water source ( $(1 . \mathrm{tfall} 001$, K.C89-105, or KC89-120) and concentration (nondiluted, or diluted by $50 \%$ )

10 Summary of separate ANOVAs used to contrast mean reproduction of Ceriodaphnia in various nominal concentrations of DCE or TCE control included

11 Summary of water quality parameters measured for Kansas City Plant samples shipped to Oak Ridge National Laboratory for toxicity testing. ......

12 Concentrations of DCE and TCE in Ceriodaphnia toxicity tests

A-1 Percent recovery of PCB standards spiked into samples of uncontaminated (Hinds Creek) fish

A-2 Results of blind analyses of duplicate samples by packed column gas chromatography

A-3 PCB concentrations ( $\mathrm{PPCB}$ ) in Hinds Creek reference site fish

B-1 Concentrations of PCBs and other daca for sunfish and channel catfish from sites in the Blue River (BLK), Indian Creek (ICK), and Boone Creek (BCK) receiving outfall ()()1 at the Kansas City Plant 


\section{ABBREVIATIONS AND ACRONYMS}

\begin{tabular}{|c|c|}
\hline ANOVA & Analysis of variance \\
\hline BLK & Blue River kilometer \\
\hline DCE & 1,2-dichloroethene \\
\hline DOE & U.S. Department of Energy \\
\hline ECD & Electron capture detection \\
\hline EPA & U.S. Environmental Protection Agency \\
\hline FDA & U.S. Food and Drug Administration \\
\hline $\mathrm{GC}$ & Gas chromatography \\
\hline ICK & Indian Creek kilometer \\
\hline $\mathrm{KCP}$ & Kansas City Plant \\
\hline $\mathrm{MDC}$ & Missouri Departnient of Conservation \\
\hline NPDES & National Pollutant Discharge Elimination System \\
\hline ORNL & Oak Ridge National Laboratory \\
\hline PC.B & Polychlorinated biphenyl \\
\hline PCB-1248 & $\begin{array}{l}\text { PCB extract from fish best characterized by comparison with Aroclor } 1248 \\
\text { standard }\end{array}$ \\
\hline PCB- 1254 & $\begin{array}{l}\text { PCB extract from fish best characterized by comparison with Aroclor } 1254 \\
\text { standard }\end{array}$ \\
\hline PCB-1260 & $\begin{array}{l}\text { PCB extract from fish best characterized by comparison with Aroclor } 1260 \\
\text { standard }\end{array}$ \\
\hline QA & Quality Assurance \\
\hline $\mathrm{TCE}$ & trichlorotethene \\
\hline USFWS & U.S. Fish and Wildlife Service \\
\hline $\mathrm{BCK}$ & Boone Creek kilometer \\
\hline
\end{tabular}




\section{EXECUTIVE SUMMARY}

The Kansas City Plant (KCP) is part of a federal complex located in south Kansas City, Missouri. The plant, operated by Allied-Signal Inc., Kansas City Division for the U.S. Department of Energy (DOE), occupies 137 of the 300 acres covered by the complex. Blue River and its tributary Indian Creek receive surface water runoff, discharges permitted under the National Pollutant Discharge Elimination System (NPDES), and groundwater from the complex. Indian Creek also receives runoff from residential and commercial facilities and discharges from a sewage treatment plant upstream from the KCP. Blue River, a tributary of the Missouri River, receives runoff from an urban area, including a large landfill downstream from the $\mathrm{KCP}$.

Site characterization and remedial activities have been conducted at the KCP since 1983. DOE and the U.S. Environmental Protection Agency (EPA) entered into an Administrative Order governing all environmental restoration activities being conducted at the KCP.

Polychlorinated biphenyls (PCBs) have been detected in outfall 002 and in soils in various locations around the KCP. The Missouri Department of Conservation (MDC) found that both carp and channel catfish collected from the Blue River were contaminated with PCBs and chlordane; however, the source of this contamination was not identified. Trichloroethene (TCE) and 1,2-dichloroethene (DCE) are present in some wells adjacent to the Blue River; both TCE and DCE have been detected in outfall (O)1.

To assess the biological significance of $\mathrm{PCB}$ and chlorinated solvent contamination from the KCP and to determine whether the KCP was a significant source of PCB contamination in fish, two separate studies were conducted by staff members of Oak Ridge National Laboratory (ORNL). This report presents the results of those studies.

\section{BIOACCUMULATION MONITORING}

Sunfish have been used successfully to monitor $\mathrm{PCB}$ contamination around facilitics similar to the KCP. Green sunfish are common in Indian Creek and the Blue River in the vicinity of KCP and were therefore selected as the primary species to monitor in this study. follows:

Eight sunfish were collected at each of eight sites in the vicinity of the KCP as

Sites $1 \& 2$ local reference sites, including at site on Indian Creek upstream from the bridge at Holmes Road and on the Blue River upstream from the Interstate 435 bridge.

Sites 3-5 Indian Creek at Lydia Drive (downstream from outfall (0)3 but upstream from outfall (O)2), Indian Creek near the railroad bridge (downstream from outfall $(0) 2)$, and Boone Creek into which outfall (0)1 discharges.

Sites 6-8 Blue River at 95th Street (where the (0)3/()()4 and 002 discharges to Indian Creek are further diluted by the Blue River), Blue River below Prospect Avenue Bridge (where the (O)1 discharge is diluted in the Blue River), and Blue River near Swope Park.

Hinds Creek, a stream in eastern Tennessee that has served as a reference site for PCB studies on the Oak Ridge Reservation for five years and has been demonstrated to be free of PCB contamination, served as a third reference site. 
Although sunfish provide an indication of recent, location-specific PCB exposure, other species are likely to accumulate higher concentrations of PCBs in the same environment. Given its abundance and importance as a food/sport fish, channel catfish was selected as the species used to estimate the maximum degree of contamination in the Blue River fishery in the vicinity of KCP. Six catfish were collected from the Blue River downstream of the Prospect Avenue Bridge, and six more were collected from the upstream reference site on the Blue River. No channel catfish were found in the reference site on Indian Creek.

PCB analyses were conducted at the ORNL Analytical Chemistry Division using EPA procedures that involve extraction with methylene chloride followed by adsorption column cleanup, solvent exchange, and evaporative concentration prior to analysis by gas chromatography/electron capture detection. PCBs were analyzed using both capillary (screening/identification) and packed column (PCB quantification) procedures.

Concentrations of PCBs below the U.S. Food and Drug Administration (FDA) tolerance level $(2 \mu \mathrm{g} / \mathrm{g})$ were detected both in sunfish and catfish collected in the vicinity of the KCP. The highest concentrations of PCBs in sunfish $(0.40$ and $0.35 \mu \mathrm{g} / \mathrm{g}$ ) were found at the two downstream sites nearest KCP outfall 002 . Sunfish from the upstream reference sites on the Blue River and Indian Creek contained much lower concentrations of PCBs $(0.11$ and $0.07 \mu \mathrm{g} / \mathrm{g}$, respectively). Sunfish from Boone Creek (BCK 0.2), into which outfall 001 discharges, contained $0.31 \mu \mathrm{g} / \mathrm{g}$ PCBs.

The results of packed column analysis of PCBs in individual catfish were consistent with capillary column results on composite samples. PCBs averaged $0.78 \pm 0.20$ and 0.92 $\pm 0.07 \mu \mathrm{g} / \mathrm{g}$ in fish from the Blue River reference site and the Blue River below Prospect Avenue, respectively. The maximum concentration reported was $1.44 \mu \mathrm{g} / \mathrm{g}$; four of twelve fish exceeded $1 \mu \mathrm{g} / \mathrm{g}$.

Chlordane was expected to be found in fish samples from the Blue River, based on previous studies by the MDC, but chlorinated pesticides were not found at concentrations significantly greater than analytical detection limits in either sunfish or catfish composite samples.

Conclusions concerning site specific sources, and the relative importance of $K_{2} C P$ sources versus upstream (or, in the case of catfish, downstream) are limited when the degree of contamination is near detection limits, as in this study. The following conclusions, though, appear valid:

1. Sunfish in the Blue River/Indian Creek near the KCP contain higher concentrations of PCBs than sunfish from uncontaminated reference sites.

2. PCB contamination in sunfish from the Blue River/Indian Creek is well below the FDA tolerance level $(2 \mu \mathrm{g} / \mathrm{g})$ and substantially lower than that observed at DOE facilities in Kentucky and Tennessee.

3. The PCB mixtures found in fish were predominantly tetra- and pentachlorinated biphenyls. Such mixtures would be consistent with a source containing these and less chlorinated isomers, such as Aroclor 1242/1248.

4. $\mathrm{PCB}$ contamination $(\sim 0.1 \mu \mathrm{g} / \mathrm{g}$ in sunfish) may be present in Indian Creek upstream from KCP discharges. Sources of this contamination could include commercial facilities and the sewage treatment plant. 
5. Fish from Boone Creek below outfall 001 contained above background PCB concentrations, similar to those in fish from BLK 27.

6. No evidence was found to suggest that either outfall $(0) 1$ or outfall $(0) 3 / 004$ impact PCB concentrations in sunfish in the Blue River or Indian Creek.

7. Channel catfish from the Blue River upstream and downstream of KCP contain higher PCB contamination, but PCB levels in catfish were still below the FDA tolerance level. Because of the wider range of this species and the absence of a clear difference in contamination between BLK 31 and BLK 25, no association (negative or positive) can be made between contamination in this species and the $\mathrm{KCP}$.

8. Channel catfish would be expected to contain several times higher concentrations than sunfish from the same location because of the higher lipid content in catfish. Thus, the PCB concentrations observed in Blue River catfish are consistent with the concentrations in sunfish.

The weight of scientific evidence supports the conclusion that the KCP is one of several sources of PCB contamination in the lower reaches of Indian Creek and the Blue River; however, the magnitude of the KCP contribution to this PCB contamination could not be quantified by this study.

\section{TOXICITY TESTING}

Toxicity tests with Ceriodaphnia dubia (a freshwater microcrustacean) are often used in the NPDES permitting process to estimate the toxicity of effluents and ambient waters. When used for toxicity monitoring and environmental compliance purposes, tests with this organism are typically conducted according to procedures specified in EPA method 1002.0. EPA method 1002.0, though, involves the use of small volumes of water in open-topped beakers. Thus, this method cannot yield accurate estimates of toxicity when volatile organics are important toxicants. In this study, we modified EPA method 1002.0 to provide more accurate estimates of toxicity of water from outfall ()01 and from two wells w here DCE and TCE have been detected. We also conducted Ceriodaphnia toxicity tests, using the modified procedure, to evaluate the toxicity of pure TCE, pure 1,2-cis DCE, and two mixtures of TCE and DCE.

Water samples were collected from KCP wells KC89-120 and KC89-105 and from outfall 001 on April 24, 1991. Samples were shipped on ice to ORNL for toxicity testing.

One test involved a comparison of Ceriodaphnia survival and reproduction in serum bottles containing control water, water from KC89-120, water from KC89-105, and water from outfall (0)1. Ceriodaphnia survived and reproduced in sealed serum bottles that contained control water. However, Ceriodaphnia added to serum bottles containing water from outfall (0)1 or from wells KC89-105 or KC89-120 died in $<24 \mathrm{~h}$ (in water from 00) 1 and $\mathrm{KC} 89-105)$, or survived but produced no offspring (KC89-120).

Another test, conducted using aerated samples, also yielded clear-cut results: survival of Ceriodaphnia was $85 \%$ to $100 \%$ in all samples, and Ceriodaphnia in all samples had at least some reproduction.

T'o definitively establish the relationship between biological effects and the presence of the volatile organics, we conducted Ceriodaphnia tests to quantify the toxicity of pure 1,2-cis DCE, pure TCE, and two mixtures of DCE and TCE. DCE and TCE were each 
tested at three concentrations; the concentrations of DCE were $300 \mu \mathrm{g} / \mathrm{L}, 200 \mu \mathrm{g} / \mathrm{L}$, and $100 \mu \mathrm{g} / \mathrm{L}$, and those of TCE were $150 \mu \mathrm{g} / \mathrm{L}, 75 \mu \mathrm{g} / \mathrm{L}$, and $50 \mu \mathrm{g} / \mathrm{L}$. One of the DCE-TCE mixtures, referred to as the high-concentration mixture, contained $200 \mu \mathrm{g} / \mathrm{L}$ of DCE and $75 \mu \mathrm{g} / \mathrm{L}$ of TCE; the other mixture, referred to as the low-concentration mixture, contained $1(0) \mu \mathrm{g} / \mathrm{L}$ of DCE and $50 \mu \mathrm{g} / \mathrm{L}$ of TCE.

A weak dose-response pattern between concentration and Ceriodaphnia reproduction was detected for each compound alone: reproduction in highest concentration was significantly lower than it was in lower concentrations $\left(p=0.0464\right.$ with $\mathrm{DF}_{3,20}$ for $\mathrm{DCE}$, and $p=0.0117$ with $\mathrm{DF}_{3,20}$ for TCE). It is likely that the chronic toxicity "detection limit" of Ceriodaphnia for DCE and TCE was near the lowest concentrations that were tested (i.e., $50 \mu \mathrm{g} / \mathrm{L}$ for $\mathrm{TCE}$ and $100 \mu \mathrm{g} / \mathrm{L}$ for $\mathrm{DCE}$ ). Ceriodaphnia reproduction was greater in. the low-concentration mixture of DCE and TCE than it was in the high-concentration mixture (12.2 \pm 0.4 offspring versus $9.9 \pm 1.1$ offspring, respectively), but this difference was not statistically significant.

Results of the toxicity tests support the following conclusions:

1. TCE and DCE were both detected in water samples from KC89-105 and KC89-120, but the concentrations of these two materials were about ten times lower than those required to reduce reproduction or survival of Ceriodaphnia in tests with pure TCE, pure DCE, or TCE and DCE in mixtures. Thus, the concentrations of TCE and DCE in groundwater near the wells are unlikely to be toxic to other aquatic biota in the receiving streams.

2. Water from $\mathrm{KC} 89-105$ and $\mathrm{KC} 89-120$ did not contain nonvolatile contaminants at toxic concentrations: when aerated, water from these two wells supported higher levels of Ceriodaphnia survival and reproduction.

3. Water from outfall 001 was acutely toxic to Ceriodaphnia. However, this outfall receives once-through cooling water that has been chlorinated by the water supplier before it is used by the KCP. The concentrations of TCE and DCE in this water were well below those needed to affect Ceriodaphnia. Thus, chlorine probably caused or contributed to this outfall's toxicity.

4. The Ceriodaphnia test, as modified to be conducted in sealed serum bottles, can be used to provide reliable quantitative estimates of the acute or chronic toxicity of volatile organic compounds when sufficient dissolved oxygen is present in the sample. 


\section{OVERVIEW}

The Kansas City Plant (KCP) is part of a federal complex located in a commercial/residential area 13 miles south of downtown Kansas City, Missouri, within the incorporated city limits. The plant, operated by Allied-Signal Inc., Kansas City Division for the U.S. Department of Energy (DOE), occupies 137 of the 300 acres covered by the complex. Blue River and its tributary Indian Creek receive surface water runoff and groundwater from the complex (Fig. 1). Indian Creek also receives runoff from residential and commercial facilities and discharges from a sewage treatment plant upstream from the KCP. Blue River, a tributary of the Missouri River, receives runoff from an urban area, including a large landfill downstream from the $\mathrm{KCP}$.

Site characterization and remedial activities have been conducted at the KCP since 1983. DOE and the U.S. Environmental Protection Agency entered into an Administrative Order of Consent on June 23, 1989. This order now governs all environmental restoration activities being conducted at the KCP. One of thos z environmental restoration activities is the Resource Conservation and Recovery Act Facility Investigation (RFI) for the Northeast Area at the KCP. This document presents results of one set of studies in support of that RFI.

Polychlorinated biphenyls (PCBs) have been detected in outfall 002 (Fig. 1) and in soils in various locations around the KCP. Monitoring conducted by the Missouri Department of Conservation found that both carp (Cyprinus carpio) and channel catfish (Ictalurus punctatus) collected from the Blue River were contaminated with PCBs and chlordane (McGrath 1988a,b; Czarmezki, J.M. 1989); however, the source of contamination was not identified.

Blue River and Indian Creek are classified as Metropolitan No-Discharge Streams by the state of Missouri. Recent monitoring of outfalls 001,003, and 004 has not revealed detectable concentrations of PCBs (M. E. Stites, Allied-Signal Kansas City Division, personal communication to T. L. Ashwood, ORNL, February 7, 1992). PCBs have been measured in outfall 002, but concentrations during 1990 and 1991 were below NPDES permit limits (M. E. Stites, Allied-Signal Kansas City Division, personal communication to T. L. Ashwood, ORNL, February 7, 1992).

Groundwater monitoring has revealed the presence of chlorinated solvents, specifically trichloroethene (TCE) and 1,2-dichlorcethene (DCE) in some wells adjacent to the Blue River; both TCE and DCE have been detected in outfall 001 (Fig. 1).

In order to assess the biological significance of PCB and chlorinated solvent contamination from the KCP and to determine whether the KCP was a significant source of PCB contamination in fish, two separate studies were conducted by staff members of Oak Ridge National Laboratory (ORNL). Section 2 of this report presents the methodology, results, and conclusions of PCB bioaccumulation measurements in fish from both the Blue River and Indian Creek. Section 3 presents the methodology, results, and conclusions of toxicity tests conducted on water from two groundwater wells and outfall (0)1. 


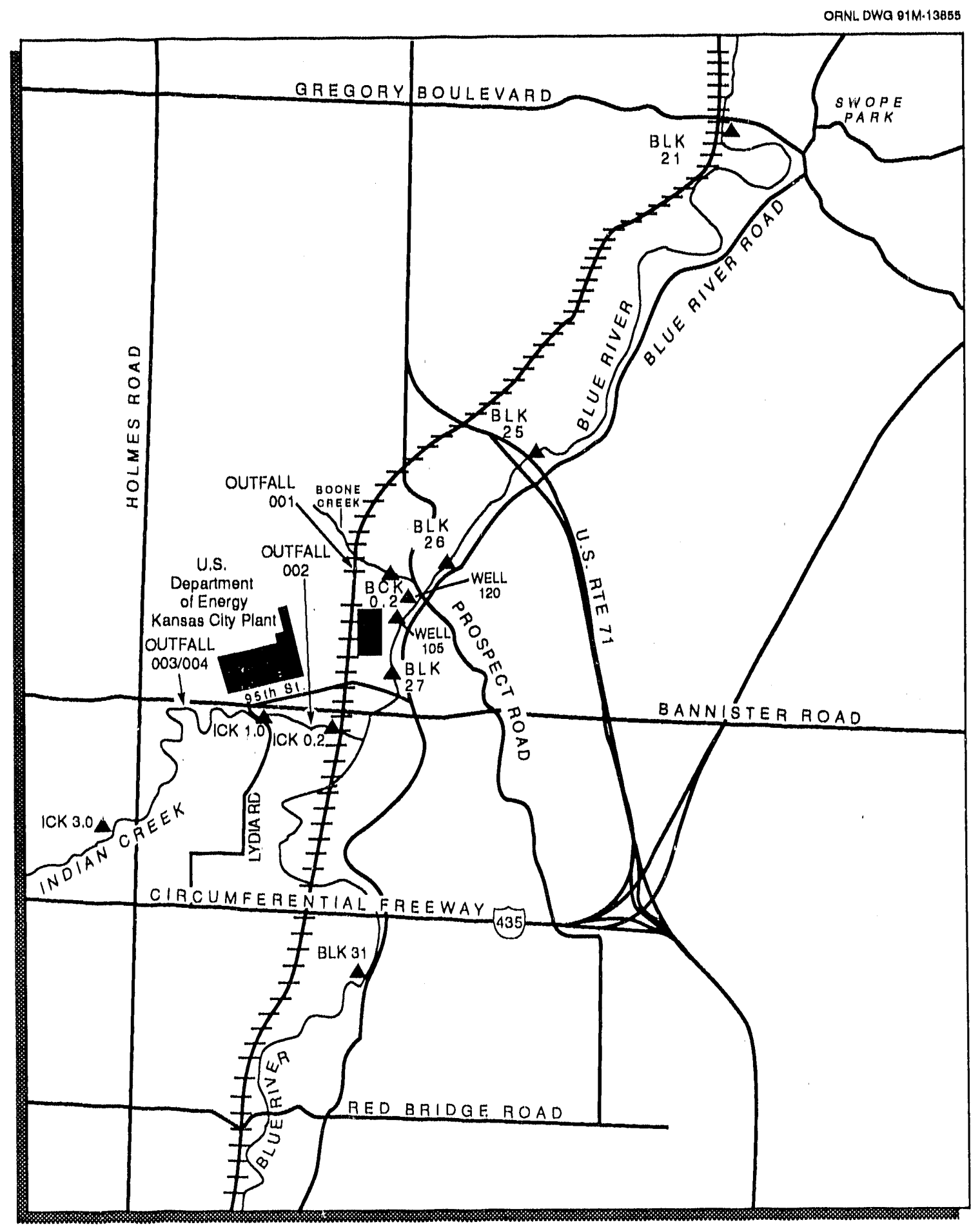

Fig. 1. Locations of fish collection sites on the Blue River and Indian Creek. 


\section{BIOACCUMULATION MONITORING}

\subsection{INTRODUCTION}

Monitoring of fish from small streams receiving point source discharges of PCBs, such as Indian Creek and Blue River, has not been widely reported. Most studies have focused on large bodies of water with multiple, dispersed point and area sources. However, sunfish (small members of the family Centrarchidae) have been successfully used to monitor PCB contamination around facilities similar to the $\mathrm{KCP}$. Bluegill (Lepomis macrochirus), redbreast sunfish (L. auritus), and rock bass (Ambloplites rupestris) have been shown to be good monitors of localized PCB contamination in east Tennessee (Rogers et al 1989; Kornegay et al. 1990b; Southworth, 1990), whereas green sunfish (L. cyanellus) and longear sunfish (L. megalotis) adequately served this purpose in western Kentucky (Rogers and Jett, 1989; Kornegay et al 1990a). Pumpkinseed (L. gibbosus) was used to monitor PCB contamination at specific sites in the Hudson River (Brown et al 1985; Skea et al 1979). Green sunfish are common in Indian Creek and the Blue River in the vicinity of KCP, and were selected as the primary species to monitor in this study.

Low, or undeteciable in routine analyses, aqueous phase concentrations of PCBs are associated with detectable PCB concentrations in fish near outfalls from DOE facilities in Oak Ridge, Tennessee, and Paducah, Kenucky. At the former site, PCBs remain below the National Pollutant Discharge Elimination System (NPDES) permit limit of $0.5 \mu \mathrm{g} / \mathrm{L}$, but sunfish collected from sites nearest these outfalls typically contain $0.5-1.0 \mu \mathrm{g} / \mathrm{g}$ PCBs (Rogers et al. 1989; Kornegay et al.1990a). Sunfish from a stream receiving PCB-contaminated $(0.1-0.2 \mu \mathrm{g} / \mathrm{L})$ discharges at the Paducah Gaseous Diffusion Plant contained several $\mu \mathrm{g} / \mathrm{g}$ PCBs at a site near the outfalls (Rogers and Jett 1989; Kornegay et al. 199() $\mathrm{b}$ ), with most fish exceeding the $2 \mu \mathrm{g} / \mathrm{g}$ tolerance limit set by the U.S. Food and Drug Administration (FDA) to regulate contamination in fish and shellfish in interstate trade (FDA 1984). Although factors such as dilution of the effluents by receiving waters play a critical role in determining the impact of a PCB-contaminated discharge in a stream (effluents at the facilities in Tennessee and Kentucky supply most of the flow in the receiving streams), it is likely that $\mathrm{PCB}$-contaminated discharges at the $\mathrm{KCP}$ result in elevated PCB concentrations in resident fish in the vicinity of plant outfalls. PCB concentrations in sunfish collected downstream from PCB-contaminated discharges in both Tennessee and Kentucky showed a pronounced downstream decrease that was useful for demonstrating whether the suspected PCB source was in fact the cause of the contamination (Southworth 1990; Kornegay et al. 199()b).

In many cases, when remedial actions are implemented to clean up contaminated soil, a pulse of contaminant is released into the environment. This may result in a temporary increase in contamination of biota followed by a decrease as the pulse of the contaminant passcs through the system and the remedial actions reduce contaminant inputs to the system. Baseline data collected before remedial actions are undertaken can explain any temporary increases in contamination of organisms and confirm the effectiveness of the particular action in reducing contamination of the environment.

Actual levels of PCBs in resident biota in the vicinity of plant outfalls to Indian Creek and the Blue River were monitored as a means of ascertaining whether outfalls from the $\mathrm{KCP}$ are significant sources of biotic contamination. 
The primary objectives of this investigation were to determine (1) whether the fish in reaches of Indian Creek and the Blue River in the vicinity of the $\mathrm{KCP}$ are contaminated with PCBs, and (2) if the biota are contaminated, whether the source of the PCBs is specific outfalls at the KCP. A third objective was to establish baseline data for PCBs in biota in Indian Creek and the Blue River that can be used to assess the effectiveness of any future remedial actions aimed at reducing PCB inputs to these streams.

PCBs have very long biological half-lives in fish (Niimi and Oliver, 1983), are significantly accumulated through the food chain pathway as well as by direct uptake from water (Thomann and Connally, 1984), and are accumulated in lipids. Therefore, large, old individuals of piscivorous species that contain relatively high levels of intramuscular lipids typically have the highest PCB levels and are generally targeted in monitoring programs. Shorter-lived fish that contain lower lipid levels and occupy trophic positions farther down the food chain are generally not intensively monitored because they are less sensitive indicators of PCB contamination. However, such species (e.g. sunfish) have significant value as a monitoring tool. Short-lived species provide a time-averaged measure of PCB exposure in the recent past, and thus provide a better indicator of changes in exposure (e.g., as a result of remedial actions at a contamination site) than species whose PCB burden represents several years accumulation. Such species as sunfish that exhibit restricted territories or home ranges provide useful information on PCB exposure at the locations where they are collected. Such information cannot be obtained from older, wideranging fish. Finally, species that are abundant in a wide range of habitats, from large lakes and rivers to small streams, provide a means for tracking contamination that may originate in waters where those species typically used in PCB monitoring do not occur.

As noted previously, whereas sunfish provide an indication of recent, location-specific PCB exposure, other species are likely to accumulate higher concentrations of PCBs in the same environment. Therefore, limited numbers of a second species expected to accumulate higher PCB concentrations were collected and analyzed in order to estimate the maximum degree of contamination of fish within the system. Annual monitoring conducted by the Missouri Department of Conservation found that both carp (Cyprinus carpio) and channel catfish (Ictalurus punctatus) collected from the Blue River were contaminated with PCBs and chlordane (McGrath 1988a,b; Czarmezki, J.M. 1989; A. Buchanan, Missouri Department of Conservation, personal communication to G. R. Southworth, ORNL, February 10, 1992). PCB concentrations (Aroclor 1260) in composite samples of channel catfish collected in the Blue River a short distance upstream from KCP were $0.04,0.19$, and $<0.05 \mu \mathrm{g} / \mathrm{g}$ in $1987-1989$, respectively. PCB concentrations in carp at that site were $0.03,0.29$, and 0.33 for the same years. Channel catfish collected approximately $16 \mathrm{~km}$ downstream from the $\mathrm{KCP}$ in a heavily industrialized section of Kansas City contained 0.23 and $0.04 \mu \mathrm{g} / \mathrm{g}$ PCBs in 1986 and 1987, while carp contained $0.06,0.02,0.42$, and $0.53 \mu \mathrm{g} / \mathrm{g}$ at that site in $1986-1989$, respectively. Substantial concentrations of chlordane $(0.16-5.6 \mu \mathrm{g} / \mathrm{g})$ were found in all of these samples.

Carp were found to be less numerous than expected at sites in the Blue River; however channel catfish were abundant. Given its abundance and greater importance as a food/sport fish, channel catfish was selected as the species used to estimate the maximum degree of contamination in the Blue River fishery in the vicinity of KCP. The larger home range of this species makes it unlikely to demonstrate a close relationship between specific $\mathrm{PCB}$ sources and concentrations of PCBs in fish from those sites, as sunsish do. However, the combination of latger size, longer lifespan, higher trophic position and higher concentrations of intramuscular lipids makes it likely that this species will accumulate hydrophobic contaminants such as PCBs to as great a degree as any other species in the system. Channel catfish and carp have both been found to contain several 
fold higher concentrations of PCBs in fillets than sunrish collected from the same waters (Southworth 1990).

\subsection{METHODS}

Green sunfish were collected at eight sites in the vicinity of the KCP. Collection sites and brief descriptions of their locations are listed in Table 1. Site designation is determined by distance in kilometers from the site to the stream mouth. Thus, a site on Indian Creek $1.0 \mathrm{~km}$ upstream from its confluence with the Blue River would be designated Indian Creek km 1.0, or abbreviated as ICK 1.0. Two local reference sites were sampled: a site on Indian Creek upstream from the bridge at Holmes Road (ICK 3.0) and another site on the Blue River upstream from the U.S. Route 435 bridge (BLK 31). Hinds Creek, Tennessee, a stream that has served as a reference site for PCB studies on the Oak Ridge Reservation for five years and has been demonstrated to be free of PCB contamination, served as a third reference site. Sunfish were collected in Indian Creek at Lydia Drive, downstream from outfall 003 but upstream from outfall 002 (ICK 1.0), and near the railroad bridge dowrstream from outfall 002 (ICK 0.2 ). Sunfish were also collected from Boone Creek into which outfall 001 discharges (BCK0.2). This stream contained limited habitat and a relatively sparse fish population, therefore it was necessary to collect an additional species (bluegill) and smaller than optimum size and numbers of fish. A discolored discharge entered the creek from the industrialized site to the north near Prospect Avenue, approximately $150 \mathrm{~m}$ upstream from the Blue River. All fish were taken from the reach of Boone Creek upstream from that discharge.

Table 1. Fish sampling sites in Indian Creek and the Blue River near the Kansas City Plant (KCP)

Site Location, Description, and Species

ICK 3.0 Indian Creek km 3.0, upstream from low dam above Holmes Rd. bridge. Upstream reference site for sunfish in Indian Creek. Species - green sunfish, channel catfish were not found.

ICK 1.0 Indian Creek $\mathrm{km} \mathrm{1.0,} \mathrm{50} \mathrm{m} \mathrm{upstream} \mathrm{and} \mathrm{downstream} \mathrm{from} \mathrm{Lydia} \mathrm{Drive}$ bridge.

Site below discharges $003 /(0) 4$ but above outfall $0(02$.

Species - green sunfish.

ICK 0.2 Indian Creek $\mathrm{km} 0.2$, from railroad bridge upstream to $20 \mathrm{~m}$ below outfall 002 .

Site below all KCP discharges to Indian Creek.

Species - green sunfish.

BLK 31 Blue River km 31, from Interstate 435 bridge upstream for $\sim 600 \mathrm{~m}$.

Upstream reference site for green sunfish and channel catfish on the Blue

River.

Species - green sunfish, channel catfish.

BLK 27 Blue River km 27, from bridge at 95th street downstream $200 \mathrm{~m}$.

Site in Blue River potentially impacted by discharges to Indian Creek, but above outfall (O)1 discharge to Blue River.

Species - green sunfish. 
Table 1. continued

Site Location, Description, and Species

BLK 26 Blue River $\mathrm{km} 26$, a $200 \mathrm{~m}$ reach upstream from the power line crossing below the Prospect Ave. bridge.

Site ir the Blue River below all discharges from KCP. Species - green sunfish

BLK 25 Blue River $\mathrm{km} 25$, a $200 \mathrm{~m}$ reach immediately downstream from the U.S. 71 bridge (4 fish), and the reach at BLK 26 (2 fish).

Site in the Blue River below all discharges from KCP. Species - channel catfish.

BLK 21 Blue River $\mathrm{km} 21, \sim 1000 \mathrm{~m}$ reach from the bridge at Gregory Blvd. upstream.

Second site in Blue River farther downstream from all KCP discharges to ascertain possible presence of longitudinal decrease in contamination. Species - green surfish.

BCK0.2 Boone Creek, from immediately above the apparent discharge from industries north of the stream upstream to the railroad crossing $(\sim 400 \mathrm{~m})$. Site immediately below discharge 001 before dilution in the Blue River. Species - green sunfish, bluegill.

Hinds Creek Hinds Creek in A.nderson County, Tennessee.

Reference site containing sunfish that are uncontaminated by PCBs. Species - redbreast sunfish.

Three sites served to monitor the downstream decrease of contamination as point discharges receive additional dilution. These sites were BLK 27, where the (0)3/004 and $0(02$ discharges to Indian Creek are further diluted by the Blue River, BLK. 26, where the 001 discharge is diluted in the Blue River, and BLK 21, several kilometers downstream from all KCP discharges.

Eight sunfish specimens were collected by electrofishing at each site for individual analysis for PCBs. Wherever adequate numbers of fish were available, the collection was restricted to fish $40 \mathrm{~g}$ in size or larger in order to minimize possible bias related to size/contaminant covariance, and also to provide data directly pertinent to fish likely to be taken by sport fishermen. After completion of the collection at each site, the fish were tagged with a unique four digit tag wired to the lower jaw, placed on ice in a labeled ice chest and returned to the processing station. Each fish was then weighed, measured, and scales were taken for possible future age determination. The fish was then filleted, and the skin removed from the fillet. A 10-g sample of each sunfish was separately wrapped in heavy duty aluminum foil, labeled, and frozen until submitted for analysis by packed column gas chromatography. The remainder was similarly wrapped, frozen, and stored for later use. After returning to ORNL, 2-g portions of each archived sample were removed and composited with similar samples to yield a single composite sample of all fish from a given site. The composite samples were submitted for analysis using capillary column gas chromatography.

Channel catfish were not used to establish a relationship between source and biotic contamination, but rather to estimate the likely maximum degree of contamination in the 
system. Six catfish were collected srom the Blue River at two locations in the BLK 25 to BLK 26 reach (treated as a single site, BLK 25) and six more from the upstream reference site on the Blue River (BLK 31). No channel catfish were found in the reference site on Indian Creek (ICK 3.0) either by electrofishing or by using slat basket fish traps. The latter collected numerous small bullheads, a relative of channel catfish; however, the bullhead is not an appropriate surrogate in a PCB study. The absence of channel catfish at ICK 3.0 precluded gaining additional information on the role of upper Indian Creek as a source of PCBs to the Blue River; however the two collections from the Blue River were judged to be adequate to achieve the primary goal of estimating the maximum degree of $\mathrm{PCB}$ contamination in fish in the vicinity of the $\mathrm{KCP}$.

Catfish collected at the sites previously mentioned were handled and processed similarly to sunfish. Because only a small portion of each large fillet is extracted for PCB analysis, the frozen fillets were homogenized using a hand meat grinder prior to removing individual samples for submission to the analytical laboratory or compositing tissue from individual fish as was done for the sunfish samples.

PCB analyses were conducted at the ORNL Analytical Chemistry Division using procedures based on PPB 12/83 (EPA 1984) and EPA 600/4-81-055 (EPA 1980). These involve extraction with methylene chloride followed by adsorption column cleanup, solvent exchange, and evaporative concentration prior to analysis by gas chromatography/electron capture detection (GC/ECD). PCBs were analyzed using both capillary (screening/identification) and packed column (PCB quantification) procedures. Packed column GC/ECD, a low-resolution, high-sensitivity procedure was used to quantify the relatively low concentrations of $\mathrm{PCBs}$ anticipated in sunfish samples. Although sensitive, this technique is subject to interferences from other organic chemicals (e.g., phthalates, pesticides) and is not ideal for distinguishing or characterizing specific PCB mixtures. Because of the likely presence of chlordane, which can interfere in packed column GC/ECD analysis, in at least some of these fish samples, and the need to better characterize the PCB mixtures extracted from fish, composite samples representing all fish (equally weighted) of each species (sunfish or catfish) collected at a site were analyzed by capillary coluran GC/ECD, which is capable of separating chlordane constituents from various $\mathrm{PCB}$ corgeners. Gas chromatography/negative ion chemical ionization mass spectrometry was utilized on composite catfish samples to confirm the presence of PCBs.

In addition to quality assurance (QA) procedures used within the analytical laboratory, some of the samples submitted were blind duplicates, reference fish known to be free of PCB contamination, and uncontaminated fish to be spiked with known amounts of PCB standards or surrogate chemicals to evaluate recovery/quantitation. The analytical laboratory annually participates in split sample QA evaluations in which replicate fish samples are analyzed for PCBs by laboratories at EPA Region IV, Tennessee Valley Authority, and Tennessee Department of Health and Environment. A summary of QA results is in Appendix A.

Statistical evaluations of the data were made using procedures and sof tware from SAS Institute, Inc. (SAS 1985a,b) for analysis of variance (ANOVA), Tukey's multiple comparison test, t-tests, and the calculation of means, standard deviations, standard errors, and coefficients of variation. 'Tests for homogeneity of variance among various data groups were conducted using Levene's test on untransformed and loge-transformed variables (Sokal and Rohlf 1981). Dunnett's test was used to compare means at specific sites with controls (Zar 1984). All comparisons were conducted using $\alpha=0.05$. 


\subsection{RESULTS}

\subsubsection{Polychlorinated Biphenyls (PCBs)}

Detailed results of all analyses are included in Appendix B.

The results of capillary column gas chromatography (GC) analysis of composite fish samples from each site are presented in Table 2. PCBs, characterized as PCB-1248 and PCB-1254, were detected in both sunfish and catfish collected in the vicinity of the KCP. Extracts of PCBs from biological tissue differ qualitatively from the commercial mixtures that are used as standirds (e.g., Aroclor 1248) and are, therefort, not referred to as Aroclors in this report. The extracts did not appear to contain PCB constituents consistent with the presence of $\mathrm{PCB}-1242$ and $\mathrm{PCB}-1260$ ). Fish selectively accumulate the more highly chlorinated, more hydrophobic constituents of PCB mixtures, thus, extracts from fish would not be expected to mirror PCB mixtures found in water, but rather would tend to resemble more highly chlorinated mixtures.

Table 2. Concentrations of PCBs ( $\mu \mathrm{g} / \mathrm{g}$ wet weight) in composite fish samples from streams near the Kansas City Plant., $a, b$

\begin{tabular}{|c|c|c|c|c|c|c|}
\hline Site & $\sum \mathrm{PCB}$ & PCB -1242 & PCB -1248 & PCB-1254 & PCB-1260) & Lipid \\
\hline $\begin{array}{l}\text { Boone Creek below } \\
\text { Outfall 001 (BCK0.2) } \\
\quad \text { Sunfish }\end{array}$ & 0.31 & $<0.01$ & 0.15 & 0.16 & $<0.02$ & 0.25 \\
\hline $\begin{array}{l}\text { Indian Creek km 3.0 } \\
\text { (ICK 3.()) } \\
\text { Sunfish }\end{array}$ & 0.07 & $<0.01$ & $<0.01$ & 0.07 & $<0.02$ & 0.09 \\
\hline $\begin{array}{l}\text { Indian Creek km } 1.0 \\
\text { (ICK } 1 .(0) \\
\text { Sunfish }\end{array}$ & $<(),() 2$ & $<(0.0) 1$ & $<0.01$ & $<0 .() 2$ & $<0.02$ & 0.56 \\
\hline $\begin{array}{l}\text { Indian Creek km } 0.2 \\
\quad \text { (ICK } 0.2) \\
\text { Sunfish }\end{array}$ & 0.35 & $<0.01$ & 0.16 & 0.19 & $<0.02$ & 0.26 \\
\hline $\begin{array}{l}\text { Blue River km } 31 \\
\text { (BLK 31) } \\
\text { Sunfish }\end{array}$ & 0.11 & $<0.01$ & 0.03 & 0.08 & $<0.02$ & 0.20 \\
\hline $\begin{array}{l}\text { Blue River km } 27 \\
\text { (BLK 27) } \\
\text { Sunfish }\end{array}$ & 0.40 & $<0.01$ & 0.19 & 0.21 & $<(0,0) 2$ & 0.33 \\
\hline $\begin{array}{l}\text { Blue River km } 26 \\
\text { (BLK 26) } \\
\text { Sunfish }\end{array}$ & 0.04 & $<(0.01$ & $<0.01$ & (0.04 & $<0 .() 2$ & 0.23 \\
\hline $\begin{array}{l}\text { Blue River km } 2.1 \\
\text { (BLK 21) } \\
\text { Sunfish }\end{array}$ & 0.24 & $<(0.01$ & 0.13 & 0.11 & $<0 .() 2$ & 0.27 \\
\hline $\begin{array}{l}\text { Hinds Creek, Tenn. } \\
\text { Sunfish }\end{array}$ & $<0.02$ & $<0.01$ & $<() .01$ & $<0.02$ & $<(),() 2$ & 0.62 \\
\hline
\end{tabular}


Table 2. continued

\begin{tabular}{ccccccc}
\hline Site & LPCB & PCB-1242 & PCB-1248 & PCB-1254 & PCB-1260) & Lipid \\
\hline $\begin{array}{c}\text { Blue River km 31 } \\
\text { (BLK 31) } \\
\text { Cattish }\end{array}$ & 1.14 & $<0.01$ & $\mathbf{0 . 7 5}$ & $\mathbf{0 . 3 9}$ & $<0.02$ & 1.7 \\
$\begin{array}{c}\text { Blue River km 25 } \\
\text { BLK 25) } \\
\text { Cattfish }\end{array}$ & 1.45 & $<0.01$ & $\mathbf{0 . 8 7}$ & $\mathbf{0 . 5 8}$ & $<0.02$ & 2.3 \\
\hline
\end{tabular}

${ }^{a}$ Each sample is a composite of 8 green sunfish or 6 channel catfish except that from Boone Creek, which is a composite of 7 bluegill and green sunfish, and Hinds Creek, which is a composite of 3 redbreast sunfish. Lipids are \% wet wt. When PCBs are not detected in a sample, the laboratory performing capillary column analyses reports the value as less than the quantitation limit, a statistically based value used for regulatory purposes. Concentrations lower than the quantitation limit are routinely detected and reported as estimated concentrations. The detection limit (not the quantitation limit) is reported in this table and is assumed to be 1/10 of the quantitation limit. Values of specific mixtures in bold face exceed quantification limits, others did not and are estimated concentrations.

$b$ The U.S. Food and Drug Adrininistration tolerance limit for PCBs in fish and shellfish sold for human consumption is $2 \mu \mathrm{g} / \mathrm{g}$ wet weight (FDA 1984).

The highest concentrations of PCBs in sunfish $(0.40$ and $0.35 \mu \mathrm{g} / \mathrm{g}$ ) were found at ICK 0.2 and BLK 27, respectively, the two downstream sites nearest KCP outfall $0(2)$. Sunfish from the upstream reference sites on the Blue River (BLK 31) and Indian Creek (ICK 3.0) contained much lower concentrations of PCBs, 0.11 and $0.07 \mu \mathrm{g} / \mathrm{g}$, respectively. Sunfish from an uncontaminated site in Anderson County, Tennessee, that has been routinely used as a uncontaminated reference site for PCB studies on the DOE Oak Ridge Reservation for 5 years, exhibited characteristically low levels, $<0.02 \mu \mathrm{g} / \mathrm{g}$. Sunfish from Boone Creek (BCK ().2), into which outfall ())1 discharges, contained $0.31 \mu \mathrm{g} / \mathrm{g}$ PCBs.

PCB contamination was not observed in fish taken at ICK 1.0, upstream from outfall $0(22$ but below the 003/004 discharges. Inexplicably, low (near background) PCB concentrations were found in the sample from BLK 26. Sunfish from the downstream site near Swope Park, BLK 21, contained slightly lower PCB concentrations $(0.24 \mu \mathrm{g} / \mathrm{g})$ than those collected nearer the plant discharges.

In order to statistically test whether PCB concentrations in fish at sites potentially impacted by KCP discharges were higher than in fish from reference sites, al one-tailed ttest was performed comparing mean concentrations of $\mathrm{PCCB}, \mathrm{PCB}-1248$, and PCB-1254 at the reference sites (Hinds Creek, BLK 31 and ICK 3.()) with those from all sites downstream from KCP discharges. Because ICK 1.() appeared to be uncontaminated, a second comparison was made using the reference sites and all sites downstream from outfall ()(2) and/or (0)1 (i.e., ICK 1.0) wals excluded). Because the variance in concentrations of PCBs among uncontaminated sites is expected to be smaller than the variance among concentrations from contaminated sites (most values from uncontaminated sites are near zero, whereas values from contaminated sites maly range widely), variances among reference and KCP-impacted sites were not assumed to be equal. Results of the statistical comparison were signilicant $(\mathrm{P} \leq(0.05)$ between reference sites and all $\mathrm{KCP}$ sites for $\mathrm{PCB}$ and PCB-1248, but not for PCB-1254. All compartisons were significant when the site upstream from ouffall ()()2 (ICK 1.()) wals excluded. 
PCB analysis of individual sunfish by packed column gas chromatography found detectable concentrations of PCBs at most sites in Indian Creek and the Blue River (Table 3). The PCB extract was characterized as predominantly PCB-1254, with lesser amounts of material characteristic of PCB-1248 and PCB-1260. Becaluse PCB concentrations of the individual mixtures were so low (generally $\leq 0.001 \mathrm{\mu g} / \mathrm{g}$ ) and packed column characterization of mixtures is a relatively imprecise tool for characterizing such mixtures, it was concluded that meaningful comparisons could best be made using estimates of total PCB concentration (summing PCB-1248, 1254, and 126() concentrations).

Table 3. Concentrations of PCBs ( $\mu \mathrm{g} / \mathrm{g}$ wet weight) in fish samples from streams near the Kansas City Plant, measured by packed column gas chromatographya

\begin{tabular}{|c|c|c|c|c|}
\hline Site & $\Sigma \mathrm{PCB}$ & PCB-1248 & PCB- 1254 & РCB -1260 \\
\hline $\begin{array}{c}\text { Bocne Creek below } \\
\text { Outfall }(0) 1^{\mathrm{b}} \\
(\text { BCK( } 0.2)\end{array}$ & $\begin{array}{l}0.20 \pm 0.06 \\
(0.03-0.51)\end{array}$ & $\begin{array}{c}0.04 \pm 0.02 \\
(<0.01-0.12)\end{array}$ & $\begin{array}{l}(0.15 \pm 0.06 \\
(0.01-(0.49)\end{array}$ & $\begin{array}{c}(0.01 \pm 0.01 \\
(<0.01-0.02)\end{array}$ \\
\hline $\begin{array}{l}\text { Indian Creek km 3.0 } \\
\text { (ICK } 3.0)\end{array}$ & $\begin{array}{l}(0.11 \pm(0.04 \\
(0.01-0.32)\end{array}$ & $\begin{array}{c}0.02 \pm(0.02 \\
(<0.01-0.13)\end{array}$ & $\begin{array}{c}(0.07 \pm 0.03 \\
(<0.01-0.20)\end{array}$ & $\begin{array}{c}(0.01 \pm 0.01 \\
(<0.01-0.03)\end{array}$ \\
\hline $\begin{array}{l}\text { Indian Creek km 1.() } \\
(\text { ICK } 1.0)\end{array}$ & $\begin{array}{c}(0.14 \pm 0.06 \\
(<0.01-0.46)\end{array}$ & $\begin{array}{c}0.01 \pm(0.0) \\
(<0.01-(0.02)\end{array}$ & $\begin{array}{c}(0.09 \pm 0.04 \\
(<0.01-0.37)\end{array}$ & $\begin{array}{c}(0.04 \pm 0.02 \\
(<0.01-0.16)\end{array}$ \\
\hline $\begin{array}{l}\text { Indian Creek } \mathrm{km} 0.2 \\
\quad(\operatorname{ICK}(0.2)\end{array}$ & $\begin{array}{c}0.09 \pm 0.02 \\
(<0.01-0.17)\end{array}$ & $\begin{array}{c}0.03 \pm 0.01 \\
(<0.01-0.09)\end{array}$ & $\begin{array}{c}0.05 \pm 0.02 \\
(<0.01-0.12)\end{array}$ & $\begin{array}{c}0.02 \pm 0.01 \\
(<0.01-0.05)\end{array}$ \\
\hline $\begin{array}{l}\text { Blue River km } 31 \\
\text { (BLK31) }\end{array}$ & $\begin{array}{c}0.02 \pm(0.01 \\
(<0.01-0.07)\end{array}$ & $\begin{array}{c}<0.01 \\
(<0.01-(0.02)\end{array}$ & $\begin{array}{c}(0.02 \pm 0.01 \\
(<0.01-(0.05)\end{array}$ & $\begin{array}{c}<0.01 \\
(<0.01-(0.02)\end{array}$ \\
\hline $\begin{array}{l}\text { Blue River km } 27 \\
\text { (BLK27) }\end{array}$ & $\begin{array}{l}(0.15 \pm 0.06 \\
(0.03-0.49)\end{array}$ & $\begin{array}{c}(0.04 \pm 0.03 \\
(<0.01-0.2(0)\end{array}$ & $\begin{array}{l}(0.10 \pm 0.03 \\
(0.02-0.26)\end{array}$ & $\begin{array}{c}(0.02 \pm 0.00) \\
(<0.01-(0.04)\end{array}$ \\
\hline $\begin{array}{l}\text { Blue River km } 26 \\
\text { (BLK 26) }\end{array}$ & $\begin{array}{c}(0.03 \pm 0.01 \\
(<0.01-0.06)\end{array}$ & $\begin{array}{c}<(0.01 \\
(<0.01-(0.0 .3)\end{array}$ & $\begin{array}{c}0.02 \pm 0.01 \\
(<0.01-0.06)\end{array}$ & $\begin{array}{c}0.01 \pm 0 .(0) \\
(<0.01-(0.01)\end{array}$ \\
\hline $\begin{array}{l}\text { Blue River km } 21 \\
\text { (BLK 21) }\end{array}$ & $\begin{array}{l}(0.22 \pm 0.14 \\
(0.01-1.2())\end{array}$ & $\begin{array}{c}0.08 \pm 0.07 \\
(<0.01-(0.55)\end{array}$ & $\begin{array}{l}(0.14 \pm 0 .(08 \\
(0.01-0.65)\end{array}$ & $\begin{array}{l}<0 .() 1 \\
(<0.01)\end{array}$ \\
\hline $\begin{array}{l}\text { Hinds Creek, Tenn, } \\
\text { Redbreast sunfishb }\end{array}$ & $\begin{array}{c}(0.04 \pm 0.02 \\
(<0.01-0.17)\end{array}$ & $\begin{array}{c}(0.01 \pm(0.00) \\
(<(0.01-0.02)\end{array}$ & $\begin{array}{c}0.0 .3 \pm 0.02 \\
(<0.01-0.16)\end{array}$ & $\begin{array}{l}<0 .() 1 \\
(<(),() 1)\end{array}$ \\
\hline $\begin{array}{c}\text { Blue River km } 31 \\
\text { (BLK. K } 1 \text { ) } \\
\text { Channel catfishb }\end{array}$ & $\begin{array}{l}(0.78 \pm 0.20 \\
(0.28-1.44)\end{array}$ & $\begin{array}{c}(0.06 \pm 0.04 \\
(<0.01-0.28)\end{array}$ & $\begin{array}{l}(0.71 \pm 0.17 \\
(0.27-1.4())\end{array}$ & $\begin{array}{c}(0.01 \pm 0.01 \\
(<0.01-(0.0 .3)\end{array}$ \\
\hline $\begin{array}{l}\text { Blue River km } 25 \\
\text { (BLK25) }\end{array}$ & $\begin{array}{l}(0.92 \pm 0.07 \\
(0.64-1.10)\end{array}$ & $\begin{array}{l}(0.15 \pm(0.01 \\
(0.11 \cdot 0.19)\end{array}$ & $\begin{array}{l}0.72 \pm 0.06 \\
(0.43-0.9(0)\end{array}$ & $\begin{array}{c}(0.05 \pm 0.04 \\
(<0.01-(0.22)\end{array}$ \\
\hline
\end{tabular}

Channel cattishb

"Fish are green sunfish ( $n=8$ fish/site) unless otherwise noted. Results are presented as mean \pm SE with the range in parentheses.

$b_{n}=6$ cattish per site in Blue River, 7 redbreast sunfish at Hinds Creek, 3 green sunfish and 5 bluegill at BCK().2 
The mean concentrations of PCBs in sunfish did not exceed $0.25 \mu \mathrm{g} / \mathrm{g}$ at any site, including those immediately downstream from historically PCB contaminated discharges $(0) 1$ and $(0) 2$. The highest mean concentration was $(0.22 \mu \mathrm{g} / \mathrm{g}$ at BLK 21 , followed by (0.20) $\mu \mathrm{g} / \mathrm{g}$ at $\mathrm{BCK}(0.2$ and $0.15 \mu \mathrm{g} / \mathrm{g}$ at BLK 27 . PCB concentrations typical of uncontaminated sites were found in sunfish at the BLK 31 and Hinds Creek reference sites; however, PCBs averaged $0.14 \mu \mathrm{g} / \mathrm{g}$ at the ICK 0.3 reference site.

A clear association between PCB concentrations in sunfish and KCP outfalls was not apparent in this data set. No increase in PCB concentrations was observed at ICK 0.2 or ICK 1.0 when compared to the upstream reference site, ICK 3.0 (Table 3). In the Blue River, mean PCB concentrations at BLK 27 and BLK 21 were higher than that at the BLK 31 reference site, but the mean concentration at BLK 26 was typical of background sites.

Statistical comparisons of nean PCB concentrations between KCP sites and reference sites were made using Dunnett's test on loge-transformed data. The mean (geometric) PCB concentrations in sunfish were statistically $(p \leq 0.05)$ higher than those at the Hinds Creek and BLK 31 reference sites at only two sites, BCK().2 and BLK 27. No sites differed statistically from the ICK 3.0 reference site. Results of Tukey's multiple comparison test (again using $\log _{c^{-}}$transformed data) indicated no significant differences among PCB concentrations at all non-reference sites.

In order to conduct a comparison similar to that carried out with the capillary column data, the reference site data (Hinds Creek, ICK 3.(), and BLK 31) and KCP site data (ICK 1.0, ICK 0.2, BLK 27, BLK 26, BLK 21, and BCK(0.2) were pooled and compared using a one-tailed t-test with the assumption of unequal variances. Although the mean concentrations of PCBs in both groups were similar $(0.14 \mathrm{vs}(0.06 \mu \mathrm{g} / \mathrm{g})$, the difference was statistically significant $(p \leq 0.05)$, as was the case for the same comparison using the capillary column datá.

PCB concentrations measured by the packed column procedure were generally lower than those reported by capillary column analysis (Tables 2,3 ). However, comparison of the difference between paired (by site) measurements of mean PCB concentrations by the two methods indicated the the overall difference was small $(0.06 \mu \mathrm{g} / \mathrm{g})$ and not statistically significant $(p>0 .(05, t$-test of mean difference among paired comparisons).

Concentrations of PCBs measured in catfish using capillary column gas chromatography were five to ten times higher in catfish than in sunfish from similar locations (Table 2). This is consistent with observed differences between sunfish and catfish accumulation of PCBs found in sites on the Oak Ridge Reservation in Tennessee (Southworth 199(); Loar 1989; 1990); 1991). Unlike the levels observed in sunfish, PCB concentrations in channel catfish were much closer to the FDA tolerance limit of $2 \mu \mathrm{g} / \mathrm{g}$ (FDA 1984) that is used by many state health agencies as a guideline. The small difference between $\mathrm{PCB}$ concentrations in catfish from the upstream reference site (BLK 31) and downstream from the KCP (BLK 25), $1.14 \mathrm{vs} 1.45 \mu \mathrm{g} / \mathrm{g}$, is typical of the variability between fish samples from the same site, and does not imply any difference due to locition.

The results of packed column analysis of PCBs in individual catfish were consistent with capillary column results on composite samples. PCBs averaged (0.78 \pm 0.20 and (0.92 $\pm 0 .(17 \mathrm{Hg} / \mathrm{g}$ (mean $\pm \mathrm{SE}$ ) in fist from BL.K.1 and BLK2.5, respectively (Table 3). The maximum concentration reported was $1.44 \mu \mathrm{g} / \mathrm{g}$, and four of twelve fish exceeded $1 \mu \mathrm{g} / \mathrm{g}$ (Appendix B). The packed column procedure characterized the extract as predominantly PCB-1254, whereas the capillary column procedure reported a mixlure of PCB-1248 and PCB.-1254. Such a difference between the high and low resolution procedures is not 
unexpected (Schmitt et al 1990), and the capillary column results should be assumed to be the more reliable characterization. PCB concentrations were slightly higher at BLK2.5 than at BLK31, however the differences were not statistically significant for total PCBs or individual mixtures ( $t$-test, $p>0.05)$. As was the case in the composite analyses, mean PCB concentrations in catfish from the Blue River were much higher than those in sunfish (Table 3).

\subsubsection{Other Contaminants}

Chlordane was expected to be found in fish samples from the Blue River, in light of previous studies by the Missouri Department of Conservation (McGrath 1988a,b), which resulted in the posting of an advisory against fish consumption. However, neither specific chlordane constituents, nor materials that could be quantified as technical chlordane, were detected at significant concentrations in either sunfish or catfish composite samples (Table 4). Similarly, DDT and its metabolic residues, DDE and DDD were not found in these samples. Negative ion chemical ionization mass spectrometry of a gas chromatogram of the two catfish samplis confirmed the presence of PCB congeners, and characterized the mixture as PCB-1248 (Appendix C). Numerous extraneous non-PCB compounds, such as phthalate esters, were also detected by mass spectrometry, but not subjected to spectral analysis. The presence of phthalates may interfere with packed column PCB analyses; however, the low PCB concentrations reported by packed column analysis suggest that this was not a major problem.

Table 4. Concentrations of pesticides ( $\mu \mathrm{g} / \mathrm{g}$ wet $w \mathrm{t})$ in composite fish samples from streams near the Kansas City Plant ${ }^{a}$

\begin{tabular}{|c|c|c|c|}
\hline Site & EChlordane ${ }^{b}$ & Technical Chlordaner & EDDTd \\
\hline $\begin{array}{l}\text { Boone Creek below } \\
\text { Outfall ()() } 1(B C K() .2) \\
\text { Sunfish }\end{array}$ & 0.005 & $<0,02$ & $<() .0()) 1$ \\
\hline $\begin{array}{l}\text { Indian Creek km 3.0) } \\
\text { (ICK3.()) } \\
\text { Sunfish }\end{array}$ & $<0.001$ & $<0.02$ & $<0 .(0) 1$ \\
\hline $\begin{array}{l}\text { Indian Creek km } 1.0 \\
\text { (ICK1.()) } \\
\text { Sunfish }\end{array}$ & $<0,0(0) 1$ & $<() .() 2$ & $<(0.001$ \\
\hline $\begin{array}{l}\text { Indian Creek km } 0.2 \\
\text { (ICKO.2) } \\
\text { Sunfish }\end{array}$ & 0.006 & $<0,() 2$ & 0.005 \\
\hline $\begin{array}{c}\text { Blue River km } 31 \\
\text { (BLK31) } \\
\text { Sunfish }\end{array}$ & 0.0() 1 & $<0,() 2$ & $<(0.001$ \\
\hline $\begin{array}{c}\text { Blue River kin } 27 \\
\text { (BLK27) } \\
\text { Sunfish }\end{array}$ & (). .077 & $<() .() 2$ & $<() .(0) 1$ \\
\hline $\begin{array}{c}\text { Blue River km } 26 \\
\text { (BLK 26) } \\
\text { Sunfish }\end{array}$ & $(0.0) 1$ & $<0 .(02$ & $<() .(0) 1$ \\
\hline
\end{tabular}


Table 4. continued

\begin{tabular}{|c|c|c|c|}
\hline Site & EChlordane & Technical Chlordaner & $\Sigma \mathrm{DDT}^{d}$ \\
\hline $\begin{array}{l}\text { Blue River km } 21 \\
\text { (BLK 21) } \\
\text { Sunfish }\end{array}$ & 0.002 & $<0.02$ & $<0.001$ \\
\hline $\begin{array}{l}\text { Hinds Creek, Tern. } \\
\text { Sunfish }\end{array}$ & 0.001 & 0.01 & $<0.001$ \\
\hline $\begin{array}{l}\text { Blue River km } 31 \\
\text { (BLK31) } \\
\text { Catfish }\end{array}$ & 0.010 & $<0.02$ & 0.010 \\
\hline $\begin{array}{c}\text { Biue River km } 25 \\
\text { (BLK25) } \\
\text { Catfisin }\end{array}$ & 0.006 & $<0.02$ & 0.005 \\
\hline
\end{tabular}

${ }^{a}$ Each sample is a composite of 8 green sunfish or 6 channel catfish except that from Boone Creek, which is a composite of 5 bluegill and 2 green sunfish. Lipids are $\%$ wet weight. When PCBs are not detected in a sample, the laboratory performing capillary column analyses reports the value as less than the quantitation limit, a statistically based value used for regulatory purposes. Concentrations lower than the quantitation limit are routinely detected and reported as estimated concentrations. The detection limit (not the quantitation limit) is reported in this table and is assumed to be $1 / 10$ of the quantitation limit. All concentrations are estimated values, none exceeded quantitation limit.

$b$ $\Sigma$ Chlordane is the sum of concentrations of alpha chlordane, alpha chlordene, chlordene, gamma chlordane, gamma chlordene, and oxychlordane.

c. Tech chlordane is quantified against technical chlordane as standard.

$d$ EDDT is the sum of concentrations of DDT, DDE, and DDD.

\subsection{DISCUSSION}

The results of capillary colımn GC analysis of composite sunfish samples indicate that PCB contamination of fish in Indian Creek and the Blue River is associated with KCP discharges (X)2 and (0)1. Outfall (0)1 receives relatively little dilution after discharge into the small unnamed tributary $(\mathrm{BCK}() .2)$. If this discharge contained substantial PCB contamination, much higher $\mathrm{PCB}$ concentrations would have been expected in resident fish. A level of contamination causing $0.3 \mu \mathrm{g} / \mathrm{g}$ PCB contamination in sunfish in such a small! creek would not be likely to produce discernable contamination in sunfish in a downstream system after substantial dilution, as would be the case with the dilution of this creek in the Blue River (Southworth 199()). Thus, the presence of higher concentrations of PCBs in fish in the Blue River and Indian Creek downstream from outfall (K)2 suggest that that outfall is a significint source to fish in the Blue River; and the absence of an increase in PCB concentrations in sunfish at sites BLK26 and BLK21, downstream from the point at which discharge ()()1 enters the Blue River, indicates that outfall (0)1 is not a major source of $\mathrm{PCB}$ contamination relative to outfall ()()2.

The limited number of samples analyzed by this method makes statistical confirmation of any conclusions weak. The packed column PCB results on individual fish was designed to provide the statistical power to discriminate site specific differences. These data support the conclusion of the capillary column results, that $\mathrm{PCB}$ concentrations are higher in 
sunfish downstream from the $\mathrm{KCP}$, but do not provide evidence associnting $\mathrm{PCB}$ contamination with specific discharges. Both sets of results suggest the presence of PCB contamination in Indian Creek upstream from KCP, and the capillary column results suggest contamination in the Blue River upstream from KCP. In neither case however, are the levels high enough to provide statistical confirmation that contamination actually occurs at those sites.

The predominance of tetra- and penta-chlorinated PCB isomers (PCB-1248/1254) in the fish extracts is consistent with a source containing somewhat less chlorinated mixtures, such as PCB-1242 and PCB-1248. This is because bioconcentration potential and environmental persistence of specific PCB congeners generally increases with increasing degree of chlorination (Mackay et al. 1983; Neely 1983). In the highly contaminated upper Hudson River, where the original source was Aroclor 1016, a mixture similar to Aroclor 1242 (but with the most highly chlorinated constituents removed), fish extracts now contain predominantly PCB-1248 through PCB-1260)(Sloan et al 1983; Schmitt et al 1990). Nationwide, PCB residues in fish extracts are most commonly characterized as PCB-1254 and 1260, reflecting the higher bioaccumulation potential of the more highly chlorinated constituents (Schmitt et al. 1990). In a mathematical simulation of the fate of PCBs in Lake Michigan, the continuous addition of a mixture similar to Aroclor 1242 (predominantly trichlorobiphenyls) was predicted to produce a mixture in fish similar to PCB-1248/1254, in which pentachlorobiphenyls predominated (Neely 1983).

The degree of $\mathrm{PCB}$ contamination observed in green sunfish from the streams in the vicinity of the KCP was not high. relative to the FDA tolerance level or contamination at other DOE facilities. The highest concentration observed in capillary column analysis, 0.4 $\mu \mathrm{g} / \mathrm{g}$, was well below the FDA tolerance level (FDA 1984). PCB concentrations found in sunfish from streams near the KCP were substantially lower than concentrations found in similar species in streams at other DOE facilities. The highest mean concentration measured by the packed column procedure, $0.22 \mu \mathrm{g} / \mathrm{g}$, was even lower. PCB concentrations in sunfish (green sunfish and longear sunfish) from sites in Big Bayou and Little Bayou at the Paducah Gaseous Diffusion Plant in Kentucky were much higher, averaging $1.7 \mu \mathrm{g} / \mathrm{g}$ and $6.6 \mu \mathrm{g} / \mathrm{g}$ in each stream, respectively (Kornegay et al 1990a). Sunfish from Mitchell Branch at the Oak Ridge K-25 Plant, a small stream similar to Boone Creek at KCP, contained $1.6 \mu \mathrm{g} / \mathrm{g}$ PCBs (Kornegay et al. 1990) $)$. Three other streams at the DOE Oak Ridge facilities also contain PCB contamination: White Oak Creek at ORNL and East Fork Poplar Creek and Bear Creek at the Y-12 Plant. Sunfish (bluegill, redbreast sunfish, and rock bass) from these streams also contained higher PCB concentrations than sunfish from the KCP site, averaging about $0.6 \mu \mathrm{g} / \mathrm{g}$ at ORNL and $0.4-(0.8$ in the streams at Y-12 (Kornegay et al. 199()b). The geometric mean concentration of PCBs measured in the U.S. Fish and Wildlife Service (USFWS) National Contaminant Biomonitoring Program was $0.4 \mu \mathrm{g} / \mathrm{g}$ (Schmitt et al. 199()). PCB concentrations in sunfish from the highly contaminated upper Hudson River were typically around $5 \mu \mathrm{g} / \mathrm{g}$ in the most contaminated reaches (whole body analyses), but concentrations in fillets of redbreast sunfish were 1-2 $\mu \mathrm{g} / \mathrm{g}$ at a site many miles downstream from the source (Sloan 1987).

Very low-level PCB contamination $(\sim) .1 \mu \mathrm{g} / \mathrm{g})$ appeared to be present in sunfish from the upstream reference sites on the Blue River and Indian Creek when compared with the uncontaminated reference site, Hinds Creek, Tennessee (Table 1). Given the large areas of suburban and uban development upstream from the reference sites in both these watersheds and the presence of a large municipal wastewater treatment plant on Indian Creek above ICK3.(), it is not surprising to find evidence of minor PCB contamination. $\mathrm{PCB}$ contamination is a ubiquitous problem in highly populated areas of the United States, as indicated by the fact that PCB residues were detected in fish at 91\% of the sites sampled 
in the USFWS National Contaminant Biomonitoring Program in 1984 (Schmitt et al. 199()).

The presence of approximately $1 \mu \mathrm{g} / \mathrm{g}$ PCBs in channel catfish from the Blue River was consistent with the lower-level PCB contamination found in sunfish from that stream. The similarity in PCB concentrations in channel catfish upstream and downstream of the $\mathrm{KCP}$ cannot be taken to imply that the KCP is not the source of PCB contamination in these fish; however, neither can the contamination be assumed to originate at the KCP. As stated previously, the PCB residues in this species cannot be assumed to originate near the site of collection, since they represent a longer time averaged exposure and larger geographic area because of the greater likelihood of movement during the exposure period. The degree of contamination is not alarming, but is nevertheless significant. Although well below concentrations found in the Great Lakes and some major rivers, the concentrations of PCBs in catfish from the Blue River were substantially higher than the geometric mean concentration $(0.4 \mu \mathrm{g} / \mathrm{g})$ measured in the USFWS National Contaminant Biomonitoring Program (Schmitt et al 199()). If the catfish are assumed to be year round residents of the Blue River, then these data confirm the presence of significant PCB contamination in the Blue River. It is likely that some of this contamination is associated with the KCP; however, other ongoing sources, either upstream or downstream, and PCB-contaminated sediments within the Blue River, are possibly sources of much of it.

\subsection{CONCLUSIONS}

Background interferences, variability in chemical analyses, and natural variability in contaminant concentrations in individual fish are proportionately more significant when the concentrations of PCBs to be measured approach background levels, thus unequivocal interpretation of results becomes unlikely. The ability to reach definitive conclusions concerning site specific sources is limited when PCB concentrations are only $0.1-0.2 \mu \mathrm{g} / \mathrm{g}$, as in this case. The following conclusions represent an interpretation of the results based on statistical evaluations, support from both sets of analytical data, and professional judgement.

\subsubsection{Conclusions Supported by Both Capillary Column and Packed Column Results}

1. Sunfish in the Blue River/Indian Creek near the KCP contain higher concentrations of PCBs than sunfish from uncontaminated reference sites.

2. The degree of $\mathrm{PCB}$ contamination in sunfish from the Blue River/Indian Creek is well below the FDA tolerance level and substantially lower than that observed at DOE facilities in Kentucky and Tennessee. The data do not suggest that the KCP is a source of PCB contamination to biota in the Blue River/Indian Creek that produces an imminent threat to human health or the environment.

3. The PCB mixtures found in fish were predominantly tetra- and pentachlorinated biphenyls. Such mixtures would be consistent with a source containing these and less chlorinated isomers, such as Aroclor 1242/1248.

4. PCB contamination $(\sim) .1 \mu \mathrm{g} / \mathrm{g}$ in sunfish) may be present in Indian Creek upstream from KCP discharges. 
5. Fish from Boone Creek below outfall (0)1 contained above background PCB concentrations, similar to these in fish from BLK27. It is likely that the source of this contamination is either ongoing discharges from outfall ()()1, or residual PCB contamination in sediments of the creek.

6. There is no evidence that either outfall $0(01$ or outfall $(0) 3 /(0) 4$ impact $\mathrm{PCB}$ concentrations in sunfish in the Blue River or Indian Creek below their points of discharge to those systems.

7. Channel catfish from the Blue River upstream and downstream of KCP contain significant $\mathrm{PCB}$ contamination $(\sim 1 \mu \mathrm{g} / \mathrm{g})$. Due to the wider range of this species and the absence of a clear difference in contamination between BLK31 and BLK25, no association (negative or posi.ive) can be made between contamination in this species and the KCP.

8. Channel catfish would be expected to contain several times higher concentrations than sunfish from the same location because of the higher lipid content in catfish. Thus, the PCB concentrations observed in Blue River catfish are consistent with the concentrations in sunfish.

\subsubsection{Conclusions Supported by Only One of the Two Datasets}

1. The KCP appears to be a source of PCB contamination to fish in the extreme lower reaches of Indian Creek and the Blue River downstream from the confluence with Indian Creek.

2. Outfall 002 appears to be the primary source of contamination.

3. There is evidence of PCB contamination from sources upstream from KCP in both Indian Creek and the Blue River.

\subsubsection{Overall Conclusion}

The weight of scientific evidence supports the conclusion that the KCP is one of perhaps several sources of PCB contamination in the lower reaches of Indian Creek and the Blue River. Outfall $(X) 2$ is the most likely source of ongoing contamination, if the residues in fish result from ongoing sources rather than residual contamination in sediments and floodplain soils. 


\section{TOXICITY TESTS}

\subsection{INTRODUCTION}

Volatile organics, notably dichloroethene and trichloroethene, are present in the groundwater at the KCP. In this study we modified an EPA toxicity test method (EPA method 1(0)2.(0) Weber et a1, 1989) to provide more accurate estimates of toxicity of volatile organic compounds such as DCE and TCE. We then used the modified method to quantify toxicity of aerated and nonaerated water from outfall ()) 1 and from two wells (KC89-105 and KC 89-120), where DCE and TCE have been detected. We also conducted toxicity tests, using the modified procedure, to evaluate the toxicity of pure TCE, pure 1,2-cis DCE, and two mixtures of these two compounds. A key objective of the studies we conducted was to assess whether or not TCE or DCE in groundwater contaminant plumes poses a toxicity risk to aquatic biota in receiving systems (e.g., the Blue River).

Toxicity tests with Ceriodaphnia dubia (a freshwater microcrustacean) are often used in the National Pollutant Discharge Elimination System (NPDES) permitting process to estimate the toxicity of effluents and ambient waters (Kszos and Stewart 1991, 1992; Stewart et al. 199()). When used for toxicity monitoring and environmental compliance purposes, tests with this organism are typically conducted according to procedures specified in EPA method 1002.0 (Weber et al. 1989). EPA method 1002.0, though, involves the use of small volumes of water (e.g., $15 \mathrm{~mL}$ ) in open-topped beakers. Thus, EPA method 10(02.) cannot yield accurate estimates of toxicity when volatile organics are important toxicants. An important secondary objective in this study was to modify EPA method $10(02.0$ to allow more accurate toxicity assessments of waters containing volatile organic contaminants.

\subsection{MATERIALS AND METHODS}

\subsubsection{Water Samples}

Water samples were collected from KCP wells KC89-120 and KC89-105 and from outfall (0)1 on April 24, 1991. Two sets of samples were collected of each source. The first set of samples was $6 \mathrm{~L}$ in volume; these samples were collected by completely filling, then tightly capping, 2-L poly bottles (three bottles per source). The second sel of samples consisted of 11 serum bottles, each 6() mL in capacity. The serum bottles were filled and immediately sealed with two teflon seals; the seals were secured with a crimped aluminum seal (see Appendix D). Both samples types were shipped on ice by overnight express to the ORNL Toxicology Laboratory. Chain-of-custody procedures were used for handling and shipping the samples. Details of the methods used for sample handling are given in Appendix D.

\subsubsection{Toxicity Testing Procedures}

The samples arrived at the Toxicology Laboratory on April 25, 1991. Samples in the poly bottles were placed, unopened, in a refrigerator $\left(3^{\circ} \mathrm{C}\right)$ until used. Two serum bottles (one containing water from outfall ()()1, the other water from KC89-105) arrived broken. Less than four hours after they had arrived at the laboratory, the contents of the remaining 31 botles were warmed to testing temperatture $\left(25^{\circ} \mathrm{C}\right)$. Three serum bottles containing 
water from each source, randomly selected, plus three sealed serum bottles containing diluted mineral water used as a negative control, were then taken to ORNL's Analytical Chemistry Division for analysis of volatile organics (EPA method 8000).

On April 25, a test was conducted to compare Ceriodaphnia survival and reproduction in serum bottles containing control water (nine bottles of diluted mineral water), water from KC89-120 (eight bottles), water from KC89-105 (seven bottles), and water from outfall 001 (sever bottles). To start this test, each serum bottle was opened briefly $(<1 \mathrm{~min}$ ) and three Ceriodaphnia neonates ( $<24 \mathrm{~h}$ old) and $150 \mu \mathrm{L}$ of Ceriodaphnia food were added. The bottle was then immediately resealed and placed in a water bath $\left(25^{\circ} \mathrm{C}\right)$. The contents of each bottle were inspected daily for live adult and neonate Ceriodaphnia. On the fourth day of the test, an additional $100 \mu \mathrm{L}$ of Ceriodaphnia food was added to each bottle by injecting directly through the teflon seals; a syringe needle inserted through the seal just before the injection allowed excess fluid to escape from the bottle. This test was terminated on May 1, at the end of the sixth day. At the end of the test, the total number of live Ceriodaphnia adults and neonates was counted.

Another 6-day test was started on May 1. The procedures used in this test were very similar to those performed in the first test. The water that was tested, though, differed from that used in the first test: it was taken from the 2-L poly bottles described earlier and was aerated (by bubbling with carbon-scrubbed air for $25 \mathrm{~min}$ ) before it was poured into serum bottles. Aeration was used both to remove volatile compounds (including chlorine) that could have contributed to toxicity and to provide oxygen to the test animals. The second test also differed from the first in that each aerated water type was tested at two concentrations-full strength, and $50 \%$ of full strength. The $50 \%$ concentrations of the aerated samples were prepared by diluting full-strength water with an equal volume of diluted mineral water. Finally, the second test evaluated each full-strength water type using ten replicates $(50 \%$ concentrations of each water type were evaluated using five replicates each). As in the first test, a negative control was included.

\subsubsection{Pure-Chemical Tests}

Analyses for volatile organics revealed the presence of DCE and TCE in all three samples that were shipped to the Toxicology Laboratory (Table 5); trace levels of acetone were detected in samples from outfall 001 (Table 5). To definitively establish the relationship between biological effects and the presence of the volatile organics, we conducted Ceriodaphnia tests to quantify the toxicity of pure DCE, pure TCE, and two mixtures of DCE and TCE. These tests were started on July 23,1991, and lasted for 6 days; they were conducted in sealed serum bottles as described previously. DCE and TCE were each tested at three concentrations; the concentrations of DCE were $300 \mu \mathrm{g} / \mathrm{L}, 200$ $\mu \mathrm{g} / \mathrm{L}$, and $100 \mu \mathrm{g} / \mathrm{L}$, and those of TCE were $150 \mu \mathrm{g} / \mathrm{L}, 75 \mu \mathrm{g} / \mathrm{L}$, and $50 \mu \mathrm{g} / \mathrm{L}$. One of the DCE-TCE mixtures, referred to as the high-concentration mixture, contained $200 \mu \mathrm{g} / \mathrm{L}$ of DCE and $75 \mu \mathrm{g} / \mathrm{L}$ of TCE; the other, referred to as the low-concentration mixture, contained $100 \mu \mathrm{g} / \mathrm{L}$ of DCE and $50 \mu \mathrm{g} / \mathrm{L}$ of TCE.

Separate stock solutions of DCE and TCE were prepared to make the test solutions. The stock solutions were made by adding reagent-grade chemical to deionized distilled water $(3 \mu \mathrm{L}$ of DCE or TCE to $100 \mathrm{~mL}$ of water). The amount of DCE or TCE added to create the stock solutions below solubility limits. Test solutions were prepared to nominal concentrations immediately before use by adding an appropriate volume of stock solution to diluted mineral water; density differences between DCE (1.28) and TCE (1.5()) relative to water $(1.0())$ were taken into account in preparing nominal concentrations. The freshly prepared solutions were then poured immediately into replicate serum bottles (ten bottles 
per solution), food and three Ceriodaphnia neonates were added, and the bottles sealed. As described for the well-water and outfall-water tests, additional food was given by injection to the Ceriodaphinia in the sealed containers on the fourth day of the test. On the first and last days of the test, three replicates of each treatment were analyzed for volatile organics (analysis procedure 8240).

Table 5. Volatile organics detected in water samples shipped from the Kansas City Plant to the Oak Ridge National Laboratory for toxicity testing

\begin{tabular}{ccccc}
\hline Sample & Replicate & $\begin{array}{c}\text { DCE } \\
(\mu \mathrm{g} / \mathrm{L})\end{array}$ & $\begin{array}{c}\mathrm{TCE}^{a} \\
(\mu \mathrm{g} / \mathrm{L})\end{array}$ & $\begin{array}{c}\text { Acetone }^{a} \\
(\mu \mathrm{g} / \mathrm{L})\end{array}$ \\
\hline \multirow{2}{*}{ Outfall 001} & 1 & 4 & 2 & 9 \\
& 2 & 4 & 2 & 11 \\
KC89-105 & 3 & 4 & 2 & 9 \\
& 1 & 9 & 8 & $\mathrm{ND}$ \\
KC89-120 & 2 & 9 & 6 & $\mathrm{ND}$ \\
& 3 & 17 & 9 & $\mathrm{ND}$ \\
& 1 & 17 & 9 & $\mathrm{ND}$ \\
& 2 & 17 & 13 & $\mathrm{ND}$ \\
\hline
\end{tabular}

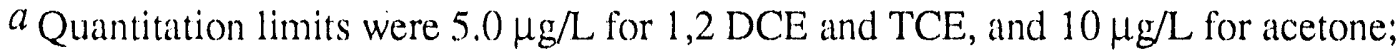
ND indicates that a constituent was not detected.

\subsubsection{Statistical Analyses}

Means and standard errors for Ceriodaphnia reproduction in the well and concentrations of DCE and TCE were computed using the Statistical Analysis System (SAS 1988). A series of one-way analysis of variance (ANOVA) tests was used to evaluate responses of Ceriodaphnia reproduction to the DCE, TCE, and the high- and lowconcentration mixtures of these chemicals. The ANOVAs were used to test for differences in reproduction in response to chemical concentration for each compound or mixture. Separate ANOVAs were also used to evaluate responses of Ceriodaphnia reproduction to the highest concentrations of DCE and TCE (controls included) and the lowest tested concentrations of DCE and TCE (controls included). A two-way ANOVA (water source and concentration) was used to evaluate Ceriodaphnia reproduction in the test that involved air-sparged samples. All ANOVAs were conducted using SAS, version 6.03 (general linear models).

\subsection{RESULTS}

\subsubsection{Toxicity Tests}

Ceriodaphnia survived and reproduced in sealed serum bottles that contained control water (Table 6). However, Ceriodaphlina added to serum bottles containing water from oulfall (0)1 or from well K(89-105 died in $<24 \mathrm{~h}$. Animals added to bottles containing 
water from well KC89-120 survived but produced no offspring. The results of this test are summarized in Table 6.

Table 6. Summary of Ceriodaphnia survival and reproduction in sealed serum bottles containing control (diluted mineral) water, water from outfali 001 , and water from wells KC89.105 or KC89.120

\begin{tabular}{cccc}
\hline Sample & $\begin{array}{c}\text { No. of } \\
\text { replicates }\end{array}$ & $\begin{array}{c}\text { No. of adults } \\
\text { (mean } \pm \text { SE) }\end{array}$ & $\begin{array}{c}\text { No. of offspring } \\
\text { (mean } \pm \text { SE) }\end{array}$ \\
\hline Control & 9 & $2.6 \pm 0.3$ & $18.3 \pm 3.2$ \\
Outfall 001 & 7 & $0^{\text {a }}$ & 0 \\
KC89-105 & 7 & $0^{\text {a }}$ & 0 \\
KC89-120 & 9 & $2.0 \pm 0.2$ & 0 \\
\hline
\end{tabular}

a Complete mortality occurred in $<24 \mathrm{~h}$.

The second test, which used air-sparged samples, also yielded clear-cut results: survival of Ceriodaphnia was $85 \%$ to $100 \%$ in the samples, and Ceriodaphnia in all samples had at least some reproduction. Significant differences $\left(p=0.0001 ; \mathrm{DF}_{3,36}\right.$, oneway ANOVA) in Ceriodaphinia reproduction were found among the four nondiluted water samples, with reproduction in outfall 001 water being much higher than that of Ceriodaphnia in any of the other water types (Table 7). Ceriodaphnia reproduction was about two times greater in diluted outfall 001 water than it was in either diluted well water sample (Table 8). Among the three KCP samples, water source and concentration explained $84.9 \%$ of the total amount of variation in Ceriodaphnia reproduction; the proportion of variance explained by water source and concentration was about equal ( $p=$ 0.001 for each factor), and the interaction term between these two factors was not significant $(\mathrm{p}=0.1767)$ (Table 9$)$.

Table 7. Summary of Ceriodaphnia survival and reproduction in air-sparged, nondiluted water samples

\begin{tabular}{lcccc}
\hline Sample & No. of replicates & No. of adults & No. of offspring $a$ & Tukey group \\
\hline Outfall $0(01$ & 10 & $3.0 \pm 0.0$ & $35.6 \pm 1.3$ & $\mathrm{~A}$ \\
Control & 10 & $3.0 \pm(0.0$ & $23.6 \pm 0.9$ & $\mathrm{~B}$ \\
KC89-120 & 10 & $3.0 \pm 0.0$ & $22.1 \pm 1.2$ & $\mathrm{~B}, \mathrm{C}$ \\
KC89-105 & 10 & $2.6 \pm 0.2$ & $18.9 \pm 1.4$ & $\mathrm{C}$ \\
\hline
\end{tabular}

${ }^{a}$ mean $\pm \mathrm{SE}$.

${ }^{b} \alpha=0.05$, minimum significant difference $=4.58, \mathrm{MSE}=14.461$. 
Table 8. Summary of Ceriodaphnia survival and reproduction in air-sparged, $50 \%$-diluted water samples

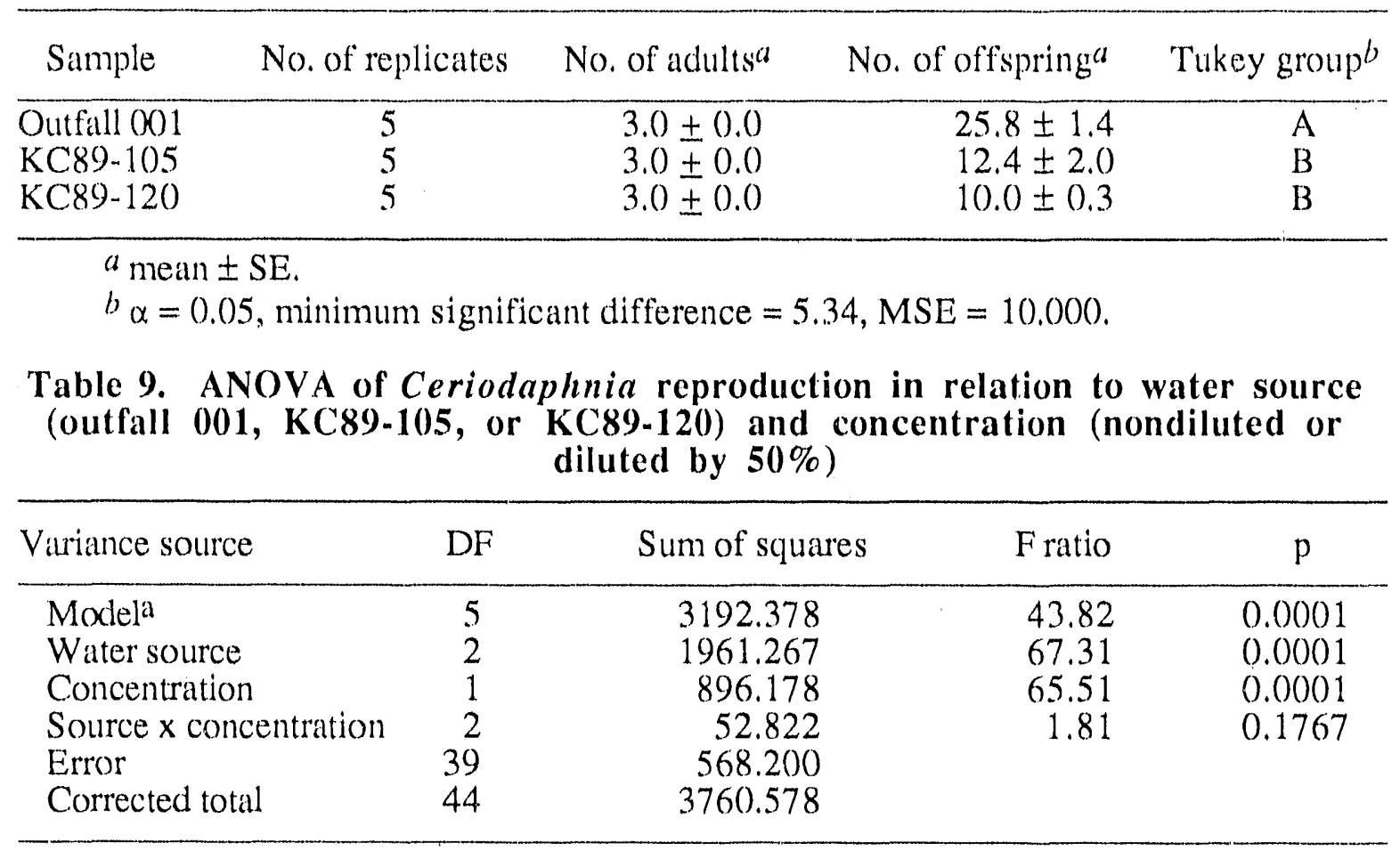

$a$ The overall $\mathrm{R}^{2}$ for the model (water source, concentration, and the interaction between these two factors) was 0.8489 .

The third test was used to determine the toxicity of pure DCE and TCE and of two mixtures of DCE and TCE. The data from this test were evaluated by ANOVAs, with separate ANOVAs being used for DCE, TCE, and the DCE-TCE mixtures. With the control excluded, a weak dose-response pattern was detected between concentration and Ceriodaphnia reproduction for aach compound alone: reproduction was significantly lower in highest concentration than in either of the two lower concentrations $(p=0.0464$ with $\mathrm{DF}_{3,20}$ for $\mathrm{DCE}$, and $\mathrm{p}=0.0117$ with $\mathrm{DF}_{3,20}$ for TCE). Concentration of the chemicals explained $32.3 \%$ (for DCE) and $41.6 \%$ (for TCE) of the total variation in reproduction (controls excluded). Ceriodaphnia reproduction in controls, the lowest concentration of $\mathrm{DCE}$, and the lowest concentration of TCE did not differ significantly $(p=0.3701$ with $\left.\mathrm{DF}_{2,15} ; \mathrm{R}^{2}=0.124\right)$. However, an ANOVA of reproduction in controls versus that in the highest concentration of DCE and the highest tested concentration of TCE did reveal significant differences among means $\left(p=0.0167\right.$ with $\left.D F_{2,15} ; R^{2}=0.421\right)$. Thus, it is likely that the chronic toxicity detection limit of Ceriodaphnia (as used in this study) for DCE and TCE was slightly higher than the lowest concentrations that were tested (i.e., 50) $\mu \mathrm{g} / \mathrm{L}$ for $T C E$ and $1(0) \mu \mathrm{g} / \mathrm{L}$ for DCE). A summary of the ANOVAs (control included) for data from the TCE and DCE tests is given in Table 10 . 
Table 10. Summary of separate ANOVAs used to contrast mean reproduction of Ceriodaphnia in various nominal concentrations of DCE and TCE, control included

\begin{tabular}{|c|c|c|c|c|c|}
\hline \multicolumn{3}{|c|}{ 1,2-cis DCE } & \multicolumn{3}{|c|}{ TCE } \\
\hline $\begin{array}{l}\text { Conc. } \\
(\mu \mathrm{g} / \mathrm{L})\end{array}$ & $\begin{array}{l}\text { Reproduction } \\
\text { (Mean } \pm S E)\end{array}$ & $\begin{array}{l}\text { Tukey } \\
\text { groupingt }\end{array}$ & $\begin{array}{l}\text { Conc. } \\
(\mu g / L)\end{array}$ & $\begin{array}{l}\text { Reproduction } \\
\text { (Mean } \pm S E)\end{array}$ & $\begin{array}{l}\text { Tukey } \\
\text { grouping }\end{array}$ \\
\hline 0 & $10.8 \pm 0.9$ & $A$ & () & $10.8 \pm 0.9$ & $\mathrm{~A}, \mathrm{~B}$ \\
\hline 100 & $10.9 \pm 0.7$ & A & 50 & $12.4 \pm 1.0$ & A \\
\hline 200 & $11.3 \pm 0.8$ & A & 75 & $9.6 \pm 1.0$ & $A, B$ \\
\hline 300 & $8.4 \pm 0.3$ & A & 150 & $7.7 \pm 0.8$ & B \\
\hline
\end{tabular}

${ }^{a}$ Means with different letters are considered to differ significantly on the basis of Tukey's test $(\alpha=0.05)$

Ceriodaphnia reproduction was slightly greater in the low-concentration mixture of DCE and TCE than it was in the high-concentration mixture $(12.2 \pm 0.4$ offspring versus $9.9 \pm 1.1$ offspring, respectively). ANOVAs showed that the $p$ values for these differences were (0.0767 (controls excluded) and 0.1822 (controls included); these two $p$ values exceed the conventionally used significance threshold $(\alpha=0.05)$.

\subsubsection{Chemical Measurements}

Concentrations of DCE, TCE, and acetone detected in the KCP samples shipped to ORNL for analysis are summarized in Table 5. At the end of the first toxicity test, measurements were made of each sample's pH, conductivity, alkalinity, and hardness; the contents of replicate serum bottles were pooled to provide enough water for this purpose. The results of these analyses are summarized in Table 11.

Table 11. Summary of water quality parameters measured for Kansas City Plant samples shipped to ()ak Ridge National Laboratory for toxicity testing

\begin{tabular}{lcccc}
\hline \multicolumn{1}{c}{ Sample } & $\mathrm{pH}$ & $\begin{array}{c}\text { Alkalinity } \\
(\mathrm{mg} / \mathrm{L})\end{array}$ & $\begin{array}{c}\text { Hardness } \\
(\mathrm{mg} / \mathrm{L})\end{array}$ & $\begin{array}{c}\text { Conductivity } \\
(\mu \mathrm{S} / \mathrm{cm})\end{array}$ \\
\hline Control & 7.49 & 67 & 94 & 198 \\
Outfall $(0) 1$ & 7.89 & 162 & 282 & 765 \\
KC89-105 & 8.01 & 570 & 628 & 1732 \\
KC89-120 & 7.91 & 472 & 634 & 16() 1 \\
\hline
\end{tabular}

No chemical measurements were made of the air-sparged samples used in the second set of toxicity tests, but concentrations of DCE and TCE were measured in the third set of Ioxicity tests, which were designed to evaluate toxicity of DCE, TCE, and DCE- TCE mixtures. The results of these measurements are summarized in Table 12 . These data were not evaluated statistically for two reasons. First, only two replicates of each treatment were analyzed, and the range in concentrations among replicates was in some instances fairly large. Nominal concentrations of "TCE, for example, were reasonably close to those measured in the sealed samples at the start of the lest, but measured concentrations of DCE in samples at the test's beginning were in some instances considerably higher than nominal 
(e.g., 20() $\mu \mathrm{g} / \mathrm{L}$ of DCE predicted, vs $327.5 \mu \mathrm{g} / \mathrm{L}$ measured; DCE in mixture, T'able 12). Second, and more important, we encountered sample-handling problems in transierring solutions from the serum botles to the smaller bottles (VOA bottles) prior to analysis by GC. In at least one instance, the data strongly suggested that the sequence in which siamples were analyzed was not the same as the sequence reported. In this instance, we assumed that co-cocurring highest concentrations of TCE and DCE were associated with the high-concentration mixture of TCE and DCE. This assumption reduced our ability to confidently relate biological responses of Ceriodaphnia to chemical concentrations of DCE or 'TCE.

Table 12. Concentrations of DCE and TCEa in Ceriodaphnia toxicity tests

\begin{tabular}{|c|c|c|c|c|}
\hline Chemical and form & $\begin{array}{c}\text { Nominal concentration } \\
(\mu \mathrm{g} / \mathrm{L})\end{array}$ & $\begin{array}{c}\text { Test start } \\
(\mu \mathrm{g} / \mathrm{L})\end{array}$ & $\begin{array}{l}\text { T'est end } \\
(\mu \mathrm{g} / \mathrm{L})\end{array}$ & $\begin{array}{l}\text { Mean daily losss } \\
\qquad(\mu g / d)\end{array}$ \\
\hline Pure DCE & 3()() & 430.0 & 155.0 & 2.75 \\
\hline Pure DCE & 20() & 210.0 & 13.5 & 1.96 \\
\hline Pure DCE & 10() & 97.5 & 9.5 & ().88 \\
\hline DCE in mixture & 2()() & 327.5 & 110.0 & 2.17 \\
\hline DCE in mixture & 10() & 78.0 & 69.5 & 0.08 \\
\hline Pure TCE & 1.50 & 94.5 & 25.0 & $(0.70$ \\
\hline Pure TCE & 75 & 79.5 & 26.0 & 0.54 \\
\hline Pure TCE & 50 & 42.5 & 9.5 & 0.33 \\
\hline 'TCE in mixture & 75 & 77.5 & 13.0 & ().6.5 \\
\hline TCE in mixture & 50 & 41.5 & $10 .()$ & () .32 \\
\hline
\end{tabular}

a Two bottles from each treatment were analyzed for volatile organics on the first and last days of the test. Constituents other than DCE and ICE were consistently below detection limits.

The rsults of these analyses suggest several main points. First, even in headspacefree, gas-tight serum bottles, concentrations of both DCE and TCE declined markedly over the 6-d test period. These losses are assumed to result largely from microbial ctegradation, though photo-dependent loss processes and/or sample-handling problems (discussed above) cannot be (liscounted. "TCE, for example, slowly decomposes in the presence of light if moisture is present (Windholz et al. 1983). As specified in EPA method 1(0)2.(), the Ceriodaphnia tests were conducted under fluorescent lamps with a day-night cycle of 8 hof larkness and 16 h of light, at an intensity of 1.5() $\mathrm{ft}$. $-\mathrm{c}$. Second, the losses in DCE and TCE did not result in the formation of detectable quantities of other volatile compounds (e.g., vinyl chloride). This point, though, does not provide strong evidence either for or against biodegradaltion, for nonvolatile degradation products (e.g., alcohols) would not be decected using the procedures employed in this study. Third, DCE alppeared to be more labile than 'TCE. In the pure chemical tests, DCE declined by $82.6 \pm 9.4 \%$ (mean \pm SE for the three pure 1 ) (C: treatments), whereas $\mathrm{TCE}$ declined by $72.8 \pm 3 .() \%$ (mean \pm SE for the three pure Tele trealments) ('lable 12). This outconce would be expected if losses resulted

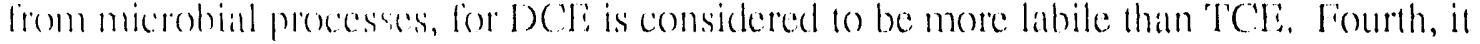
appeatred that the loss mates of DCli mal have been redueed by the presence of TCE. DCL declined by $82.6 \pm 9.4 \%$ in the absence of T'CE but by only $38.7 \%$ in the two DCE-TCE mixtures. In contrist, the mean loss rates of TCE: in the absence and presence of DCE were more similar $(72.8 \%$ vs $79.6 \%)$. 


\subsection{DISCUSSION}

The results of the chemical tests showed that water from KCP oulfall ()() 1, KC89)1(55, and KC89-120 contained both DCE and TCE. Concentrations of DCE and TCEE in $\mathrm{KC} 89$ - 105 were each $<10 \mu \mathrm{g} / \mathrm{L}$; concentrations of DCE and 'TCE in KC89-120) were slightly higher $(<20 \mu \mathrm{g} / \mathrm{L}$ and $<1.5 \mu \mathrm{g} / \mathrm{L}$, respectively; Table 5). Acetone was also detected (at a concentration of $9-11 \mathrm{\mu g} / \mathrm{L}$ ) in all three samples from outfall ()()1. Acetone, though, is notoriously detectable at low levels in blanks, controls, and noncontaminated waters (G.R. Southworth, Environmental Sciences Division, ORNL, personal communication, 1991; M. P. Maskarinec, Analytical Chemistry Division, ORNL, personal communication),

Accordingly, the acetone data for outfall $(x) 1$ should be considered to be suspect at best.

TCE and DCE are volutile and readily can escape from solution to the air. Thus, the toxicity of hese materials to aquatic biota cannot be reliably estimated by testing solutions in open-topped test chambers. A rellable EPA chronic toxicity test method using a sensitive freshwater microcrustacen (Ceriodaphnia dubia survival and reproduction test; method $1(x) 2 .(0)$ was modified to increase the accuracy of information about the toxicity of volatile organics in water. In the new method, water samples and the test organisms were enclosed in gas-tight 6()-mL serum bottles; the bottles were completely filled with test solution and were opened only when the test had been completed. The method was used to test water from KCP outfall ()01 and from wells KC89-105 and KC89-120. We also used this method to estimate the toxicity of pure DCE, pure TCE, and of mixtures of DCE and TCE.

The results of the water and pure-chemical tests show that the concentrations of TCE and DCE in water from outfall ()() 1, KC89-1()5, and KC89-120 are probably not high enough to be of much toxicity concern to acyuatic biota. In pure chemical tests, Ceriodaphinia tolerated about $200 \mathrm{\mu g} / \mathrm{L}$ of DCE, or about $75 \mu \mathrm{g} / \mathrm{L}$. TCE, without adverse effect. Additionally, water containing mixtures of TCE $(50 \mu \mathrm{g} / \mathrm{L})$ and DCE $(100 \mu \mathrm{g} / \mathrm{L})$ were not toxic to Ceriodaphnia. The sample-handling problems mentioned earlier, though, compromise a duantitative estimate of the toxicity of either TCE or DCE to Ceriodaphnia: the actual concentrations of either constituent in the test solutions could have been somewhat lower or higher than those reported, because of losses in the transferring of samples among bottles and the use of internal standards to develop estimates of DCE and TCE concentritions.

Nonatrated simples from outfall ()()1, KC89-105, and KC89-120 all adversely alfected Ceriodaphina, with water from outfall (0)1 and KC89-105 being acutely toxic (all animals died in <24 h). Concentrations of DCE and TCE in the two most toxic samples, though, were lower than in KC89-120) (Table 5, T'able 6). Thus, factors other than DCE or TCE probably accounted for the toxicity of watter from KC89-105 and oulfall (x)1. The lack of sulficient dissolved oxygen is the most plausible explanation for the toxicity of water from KC89-105. Fish asphyxiate quickly if oxygen concentrations are lower than about $2 \mathrm{mg} / \mathrm{L}$. Three considerations support the idea that inadequate concentrations of dissolved oxygen accounted for the toxicity of water from KC89-105. First, the ground water in the alyufice underlying the $\mathrm{KCP}$ is reducing and contains $<() .5 \mathrm{mg} / \mathrm{L}$ of dissolved oxygen (Korte 19)()). A concentration of oxygen as low as $(0.5 \mathrm{mg} / \mathrm{L}$. is too low to meet the metabolic needs of fist or daphnids. Second, minnow larvale placed into serum bottles containing toxic K (89)-1(5). water at the end of the first Ceriodaphinia toxicity test died in $<2$ min. Fathead minnow larvale are much hardier than Ceriodaphia in exposure 10 most toxicants, and such rapid lethality would reguire very high concentrations of a volatile compound. Also, ateration of the sample eliminated its toxicity, so either the addition of air or the removal of a volitile substance must have accounted for the reduction in toxicity. The sample, though, was odorless and no volatile compounds other than DCE and TCE were detected, even though 32 other compounds were detectable using the gas 
chromalographic analysis procedure. Thus, the addition of alr, rather than the removal of volatile organics, seems more plausible.

Water from outfall ()() I was also acutely toxic, and this toxicity was eliminated by sparging. However, outhall or stream water is much less likely than well water to be undersaturated with respect to dissolved oxygen. The concentrations of DCE and TCE in outfall (x)1 water were also lower than those in either well-water sample and so could not account for the toxicity. Compared with water from KC89-105 or KC89-120, outfall ()() I water was also moro suitable for Ceriodaphnia in terms of water quality factors such as conductivity, alkalinity, and hardness (Table 11). Finally, acetone was detected in outfall ()()1 water but not in water from wells KC89-10.5 or KC89-120. Water from outfall ()()1 does not typically contain acetone (M. E Stites, Allied-Signal Inc., Kansas City Division, personal communication, 1991), and acetone can occur as an analytical laboratory contaminant. Thus, we cannol definitively rule out acetone as a possible toxic constituent in outfall ()(0) water, although it is very improbable. We hypothesize that chlorine is the source of toxicity in outhill ()() I water. During periods of base flow, a majority of the water released via outfall ()()1 consists of city drinking water which is used as once-through coling water (M. Stites, personal communication). The stream near outfall ()()1 is visually very similar to chlorine-impacted stream sites near ORNL and the K-25 Site

(G. R. Southworth, ORNL, personal communication, to A. J. Stewart, ORNL, 1991), and chlorine at concentrations as low as $0.25 \mathrm{mg} / \mathrm{L}$ can be acutely toxic to Ceriodaphnia (Stewart et al, 1991). Chlorine is a ubiquitous oxidant, and is used at concentrations of 1 (o) $2 \mathrm{mg} / \mathrm{L}$ to control bacteria in drinking water. Chlorine is also moderately persistent if protected from labile organic matter and sunlight (Stewart et al. 1991). Collectively, these points strongly suggest that the toxicity of outfall $(0) 1$ water could reasonably be due to chlorine. However, we did not analyze ()()1 water for chlorine, and we did not test toxicity of dechlorinated outfall ()()1 water: these two kinds of tests would be needed to verify the hypothesis that chlorine accounted for the toxicity of outfall (O)1 water.

\subsection{CONCIUSIONS}

'This study highlights four findings, summarized below:

TCE and DCE were both detected in water samples from KC89-105 and KC89-120, but the concentuations of these two materials were about ten times lower than those required (o) reduce reproduction or survival of Ceriodaphnia in tests with pure TCE, pure DCE, or TCE and DCE in mixtures. Thus, the concentrations of TCE and DCE in groundwater near the wells are very unlikely to be toxic to other aqunti- biota in the receiving streams: upon entering the stream, concentrations of TCE and DCE would decline further due to dilution, microbial action, volatilization, and (possibly) photolysis.

Water from outfall ()()1 was acutely toxic to Ceriodap/hnia. The concentrations of TCE and DCE in this water, though, were well below those needed to affect Ceriodaphnia. Additionally, water (puality factor's such as conductivity, alkalinity, and hardness of outfall ()()I water were more lavorable (for Ceriodephinia) than those for water from KC89-105 or KC89.120. We hypothesize that chlorine calused or contributed to this outfall's toxicity. Ceriodaphnia responses on freshly collected nontreated and dechlorinated (with sodium thiosulfate) simples of ()() 1 water could be used to test this hypothesis.

The Cerioduphinia test, as modified to be conducted in sealed serum bottles, can be used to provide reliable yuantitative estimates of the acute or chronic toxicity of volatile organic compounds. This finding is important, for the standard Ceriodaphina test used to estimate loxicity of efluents and ambient waters is (1) considered by many regulatory 
agencies to be a sensitive, reliable test and (2) not appropriate for reliably assessing toxicity of water that contains volatile toxicants. With relatively minor modifications (notably, in the handling of the subsamples that are to be analyzed for chemical constituents), the serum-bottle test methods described in this report can be used to provide accurate estimates of the toxicity of DCEE and TC.E.

Vinyl chloride, which is toxic and carcinogenic, was not detected either in the wellwater samples or in the pure chemical toxicity tests of TCE and DCE. The microbial degradation of TCE can lead to the formation of vinyl chloride under anaerobic conditions. The results of the tests reported here suggest that under the aerobic conditions maintained in the serum-bottle tests, DCE and TCE may degrade to nonvolatile components. A timecourse study of water samples from KC89-105 or KC89-120) (spiked with TCE, DCE, or a mixture of these two compounds) could be used in conjunction with GC-MS analyses to test this hypothesis. The influence of TCE on the degradation of DCE (suggested by this study; Table 12) could be quantified using this approach as well.

\section{ACKNOWLEDGMENTS}

The authors wish to thank Mike Stites, Ed Hubert, and Dave Brown for support and guidance at the site. Nic Korte provided background information and guidance, and he reviewed a draft of the report. Marshall Adams and Lynn Kszos also reviewed an early draft of this report and provided helpful suggestions.

\section{REFERENCES}

Brown, M.P., M.B. Werner, R.J. Sloan, and K.W. Simpson. 1985. Polychlorinated Biphenyls in the Hudson River. Environ. Sci. T'echnol. 19: 656-61.

Czarmzki, James M. 1989. Contaminant Levels in Missouri Fish - 1987. Missouri Department of Conservation, Columbia, Mo.

Environmental Protection Agency (EPA). 198(). Interim Methods for Sampling and Analysis of Priority Pollutants in Sediments and Fish Tissues. EPA 6(0)/4-81-055. Environmental Monitoring and Support Laboratory, U.S. Environmenmtal Protection Agency, Cincinnati, Ohio.

Kornegay, F. , D. C. West, S. T. Goodpasture, C. W. Kimbrough, M. F. Tardiff, V. A. Jacobs, and A. R. Wilson. 199()a. Oak Ridge Reservation Environmental Report for 1989. ES/ESH-13/V1. Office of Environmental Compliance Documentation, Martin Marietta Energy Systems, Inc., and Environmental Management Staff, Oak Ridge Y-12 Plant, Oak Ridge National Laboratory, and Oak Ridge Gaseous Diffusion Plant, Martin Marietta Energy Systems, Inc.

Kornegaly, F. C., D. C. West, T. G. Jett, and J. W. Turner. 1990b. Paducah Gaseous Diffusion Plant Environmental Report for 1989. ES/ESH-13/V3. Office of Environmental Compliance and Documentation and Environmental Management Staff, Martin Marrietta Energy Systems, Inc., and Environmental Compliance Department, Paducah Gaseous Diffusion Plant, Martin Marietta Energy Systems, Inc.

Korte, N. E. 1988. Sampling Biota for PCBs at the Kansas City Plant. Letter to J. M. Loar, June 27,1988. Martin Marietta Energy Systems,Inc.

Korte, N. E. 1990). Naturally occurring arsenic in the groundwater at the Kansas City Plant. ORNL/TM-11663. Oak Ridge National Laboratory.

Kszos, L. A., and A. J. Stewart. 1991. Effort-allocation analysis of the seven-daly fathead minnow (Pimephales promelas) and Ceriodaphnia dubia toxicity tests. Environ. Toxicol. Chem. 10:67--72. 
Kszos, L. A., and A. J. Stewart. 1992. Strategic evaluation of toxicity testing for environmental compliance at Department of Energy facilities in Oak Ridge, Tennessee. Oak Ridge National Laboratory (in press).

Loar, J. M. 1989. Third Annual Report on the ORNL Biological Monitoring and Abatement Program. Draft ORNL/TM report, Oak Ridge National Laboratory.

Loar, J. M. 1990). Fourth Annual Report on the ORNL Biological Monitoring and Abatement Program. Draft ORNL/TM report, Oak Ridge National Laboratory.

Loar, J. M. 1991. Fifth Annual Report on the ORNL Biological Monitoring and Abatement Program. Draft ORNL/TM report, Oak Ridge National Laboratory.

Mackay, D., W.Y. Shiu, J. Billington, and G.L. Huang. 1983. Physical Chemical Properties of Polychlorinated Biphenyls. in Physical Behavior of PCBs in the Great Lakes, D. Mackay, S. Patterson, S. J. Eisenreich, and M. S. Simmons, Eds. Ann Arbor Science Publishers, Ann Arbor, Michigan.

McGrath, Kathleen E. 1988a. Contaminant Levels in Missouri Fish - 1985. Missouri Department of Conservation, Jefferson City, Mo.

McGrath, Kathleen E. 1988b. Contaminant Levels in Missouri Fish - 1986. Missouri Department of Conservation, Jefferson City, Mo.

Neely, W. B. 1983. Reactivity and Environmental Persistence of PCB Isomers. in Physical Behavior of PCBs in the Great Lakes, D. Mackay, S. Patterson, S. J. Eisenreich, and M. S. Simmons, Eds. Ann Arbor Science Publishers, Ann Arbor, Michigan.

Niimi, A. J. and B. G. Oliver. 1983. Biological half-lives of polychlorinated biphenyl (PCB) congeners in whole fish and muscle of rainbow trout. Can. J. Fish. Aquat. Sci. 4(): $1388-94$.

Rogers, J. G, K. L. Daniels, S. T. Goodpasture, C. W. Kimbrough, and N. L. Prince. 1989. Oak Ridge Reservation Environmental Report for 1988, Vol. 1: Narrative, summary, and conclusions. ES/ESH-8/V1. Environmental and Safety Activities, Martin Marietta Energy Systems, Inc.

Rogers, J. G. and T. G. Jett. 1989. Paducah Gaseous Diffusion Plant Site Environmental Report for 1988. ES/ESH-8/V3. Environmental and Safety Activities, Martin Marietta Energy Systems, inc., Oak Ridge, Tennessee and Environmental Complance Department, Paducah Gaseous Diffusion Plant, Martin Marietta Energy Systems, Inc.

SAS Institute, Inc. 1985a. SAS User's Guide: Basics, Version 5 Edition. SAS Institute, Inc., Cary, North Carolina

SAS Institute, Inc. 1985b. SAS User' s Guide: Statistics, Version 5 Edition. SAS Institute, Inc., Cary, North Carolina

Schmitt, C. J., J. L Zajicek, and P. H. Peterman, 1990). National Contaminant Biomonitoring Program: Residues of Organochlorine Chemicals in U.S Freshwater Fish, 1976-1984. Arch. Environ. Contam. Toxicol. 19:748-81.

Skea, J. C., H. A. Simonin, H.J. Dean, J. R. Colquhoun, J.J. Spagnoli, and G.D. Veith. 1979. Bionccumulation of Aroclor 1016 in Hudson River Fish. Bull. Environ. Contam. Toxicol. 22:332-36.

Sloan, R. J. 1987. Toxic Substances in Fish and Wildlife, Analyses since May 1,1982. Volume 6. Technical Report 87-4, New York State Dept. of Environmental Conservation, Division of Fish and Wildlife, Albany, New York.

Sloan, R. J., K. W. Simpson, R. A. Schroeder, and C. R. Barnes. 1983. Temporal Trends Toward Stability of Hudson River PCB Contamination. Bull. Environ, Contam. T'oxicol. 31:377 85.

Sokal, R. R. and I: J. Rohlf. 1981. Biometry, 2nd ed. W. H. Freeman and Company, Sin Francisco.

Southworth, (i. R. 1990). PCB concentrations in stream sunfish in relation to chronic point sources. Watter, Air, and Soil Pollution. 51:287-.96. 
Stewart, A. J., L. A. Kszos, B. C. Harvey, L. F. Wicker, G. J. Haynes, and R. D. Balley, 199(). Ambient toxicity dynamics: Assessments using Ceriodaphnia dubia and fathead minnow (Pimephales promelas) larvae In short-term tests. Environ. Toxicol, Chem, 9:367 -.79.

Stewart, A. J, W. R. Hill, and L. A, Kszos, 1991. Toxicity monitoring. In J, M, Loar (ed.), Fifth Annual Report on the ORNL Biological Monitoring and Abatement Program. Oak Ridge National Laboratory (in press).

Thomann, R, V. and J, P. Connally, 1984. Model of PCB in the Lake Michigan lake trout food chain. Environ. Sci. Technol, 18:65-.71.

U.S. Amry Engineer District. 1974. Blue River Projects, Draft Environmental Statement. U.S. Army Engineer District, Kansias City, Missouri.

U.S Department of Energy (DOE). 1977. Environmental Assessment, Kansas City Plant, Kansus City Missouri, DOE/EA-(0)()2.

U.S. Environmental Protection Agency (EPA), Interim methods for the sampling and analysis of priority pollutants in sediments and fish tissues. EPA 6(0)/4-81-()55. Environmental Monitoring and Support Laboratory, U.S. Environmental Protection Agency, Cincinnati, Ohio.

U.S. Environmental Protection Agency (EPA). 1984. Extraction and analysis of priority pollutunts in biological tissue, Method PPB 12/83. Environmental Services Division, Region IV, Analytical Support Branch, U.S. Environmental Protection Agency, Athens, Ga. Mimeo.

U.S. Food and Drug Administration (FDA), 1984. Polychlorinated Biphenyls in Fish and Shellfish: Reduction of Tolerances, Final Decision. Fed. Regist. 49:21514-520.

Weber, C. I., W. H. Peltier, T. J. Norberg-King, W. B. Horning II, F. A. Kessler, J. R. Menkedick, T. W. Neiheisel, P. A. Lewis, D. J. Klemm, Q. H. Pickering, E. L. Robinson, J. M. Lazorchak, L. J. Wymer, and R. W. Freyberg. Short-term methods for estimating the chronic toxicity of effluents and receiving waters to freshwater organisms, 2nd ed. EPA/60()/4-98/(0)1. U. S. Environmental Protection Agency, Cincinnati, Ohio.

Windholz, M., S. Budavari, R. F. Blumetti, and E. S. Otterbein (eds.). 1983. The Merck Index. Tenth edition. Merck \& Co., Rahway, New Jersey.

Zalr, J. H.. 1984. Biostatistical Analysis, Prentice Hall, Inc., Englewood Cliffs, New Jersey. 
Appendix A

QUALITY ASSURANCE DATA 
Recoverles of PCB standards splked into samples of uncontaminated Hinds Creek lish were good ('lable B-1). Recovertes of PCB-1254 and PCB-1260) spiked lnto Hinds Creek fish anulyzed by packed column GC avernged 99 \pm 12 and $94 \pm 13$ for 1 (CB 12.54 and PCB $126($ ) respectively (menn $\pm S D, n=8$ ). Recoveries of PCB spikes of sunfish composite sample analyzed by capillary column GC were $127 \%$ for PCB-1248 and 95\% for PCB 1260).

Standard reference lish known to contain PCBs were analyzed along with KCP samples in the packed column analyses. The reference fish, International Atomic Energy Agency MA-A-2 (fish flesh homogenate), had a correct value of $7.0 \pm 2.8 \mu \mathrm{g} / \mathrm{g}$ (PCB$1254+\mathrm{PCB}-126()$, mean $\pm \mathrm{SE}$ ), determined from analyses by multiple international laboratories. Results of analysis by the ORNL lab avernged $8.1 \pm(0.6 \mu \mathrm{g} / \mathrm{g}$ (mean $\pm \mathrm{SE}$, $n=6)$.

The variability among duplicate packed column analyses was somewhat disappointing (Table B-2), with the mean absolute difference anong duplicates averaging $0.17 \pm 0,15$ $\mu \mathrm{g} / \mathrm{g}$ (mean $\pm S D, n=9$ ). Wide variation was observed in several pairs of samples, while other's agreed well. Catfish sumples $(5650,(0.565)$, which contained substantially higher PCB levels, and thus proportionately less possible interferences, agreed closely. Although $0.17 \mu \mathrm{g} / \mathrm{g}$ is not an extreme degree of variability, it does impede the ability to discern differences among sites when overall PCB concentrations are low, as they are in this case.

Results of analyses of fish from a site known to be uncontaminated (Hinds Creek) were typical of those seen over several years of routine monitoring (Table B-3). While very low, obviously a non zero background level of PCBs is reported in the analyses.

Table A-1. Percent recovery of PCB standards spiked into samples of uncontaminated (Hinds Creek) fish

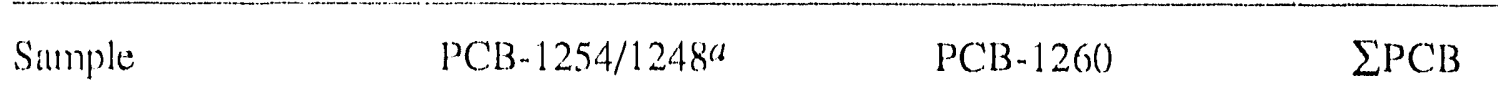

\section{Packed column}

\begin{tabular}{|c|c|c|c|}
\hline $5648 \mathrm{~A}$ & 92 & 93 & 92 \\
\hline $5678 \wedge$ & 116 & 82 & 99 \\
\hline $5678 B$ & 81 & 95 & 88 \\
\hline $5640 \wedge$ & 109 & 82 & 95 \\
\hline $5649 B$ & 1() 1 & 112 & 106 \\
\hline $5649 \mathrm{C}$ & 102 & 89 & 95 \\
\hline 579() $\mathrm{A}$ & 102 & 115 & 108 \\
\hline $5912 \mathrm{~A}$ & 8.5 & 84 & 84 \\
\hline Mein $\pm S D$ & $99 \pm 12$ & 9) 413 & $96 \pm 8$ \\
\hline \multicolumn{4}{|l|}{ Capillary columm } \\
\hline Sunfish (composite) & 127 & 95 & 111 \\
\hline
\end{tabular}

"Packed column samples were spiked with PCB-1254 and PCB-126(), while capillary column samples were spiked with PCB-1248 and PCB-126(). 
Table A-2. Results of blind analyses of duplicate samples by packed column gas chromatography

\begin{tabular}{|c|c|c|c|c|}
\hline Duplicate Puirs & PCB-1248 & $\mathrm{PCB}-1254$ & $\mathrm{PCB}-1260$ & $\sum \mathrm{PCB}$ \\
\hline 5661 & 0.03 & $\begin{array}{l}0.02 \\
0.08\end{array}$ & 0.01 & 0.06 \\
\hline 1665 & 0.08 & 0.08 & 0.07 & 0.23 \\
\hline $\begin{array}{l}5690 \\
0965\end{array}$ & $\begin{array}{r}0.02 \\
<0.01\end{array}$ & $\begin{array}{r}0.37 \\
<0.01\end{array}$ & $\begin{array}{r}0.07 \\
<0.01\end{array}$ & $\begin{array}{r}0.46 \\
<0.01\end{array}$ \\
\hline $\begin{array}{l}5393 \\
3935\end{array}$ & $\begin{array}{l}<0,01 \\
<0,01\end{array}$ & $\begin{array}{r}0.02 \\
<(0.01\end{array}$ & $\begin{array}{r}0.01 \\
<(0.01\end{array}$ & $\begin{array}{r}0.03 \\
<0.01\end{array}$ \\
\hline $\begin{array}{l}5686 \\
6865\end{array}$ & $\begin{array}{l}<0.01 \\
<(0.01\end{array}$ & $\begin{array}{r}0.02 \\
<0.01\end{array}$ & $\begin{array}{r}0.01 \\
<0.01\end{array}$ & $\begin{array}{r}0.03 \\
<0.01\end{array}$ \\
\hline $\begin{array}{l}5677 \\
776.5\end{array}$ & $\begin{array}{r}<0.01 \\
0.02\end{array}$ & $\begin{array}{l}0 .(01 \\
0.10\end{array}$ & $\begin{array}{r}<0.01 \\
0.06\end{array}$ & $\begin{array}{l}0.01 \\
0.18\end{array}$ \\
\hline $\begin{array}{l}59(0) \\
0(095\end{array}$ & $\begin{array}{l}0.01 \\
0.20\end{array}$ & $\begin{array}{l}0.05 \\
0.07\end{array}$ & $\begin{array}{l}0.02 \\
0.01\end{array}$ & $\begin{array}{l}0.08 \\
0.28\end{array}$ \\
\hline $\begin{array}{l}5921 \\
1295\end{array}$ & $\begin{array}{l}<0 .(01 \\
<0 .(01\end{array}$ & $\begin{array}{l}0.01 \\
0.06\end{array}$ & $\begin{array}{r}<0.01 \\
0.02\end{array}$ & $\begin{array}{l}0.01 \\
0.08\end{array}$ \\
\hline $\begin{array}{l}5926 \\
6295\end{array}$ & $\begin{array}{r}0.12 \\
<0.01\end{array}$ & $\begin{array}{l}0.25 \\
0.01\end{array}$ & $\begin{array}{l}0.02 \\
0.01\end{array}$ & $\begin{array}{l}0.39 \\
0.02\end{array}$ \\
\hline $\begin{array}{l}565() \\
0.565\end{array}$ & $\begin{array}{l}0.28 \\
0.25\end{array}$ & $\begin{array}{l}1.01 \\
0.95\end{array}$ & $\begin{array}{l}0.03 \\
0.06\end{array}$ & $\begin{array}{l}1.32 \\
1.26\end{array}$ \\
\hline Mein Difference \pm SD & $0.0 .5 \pm 0.06$ & $0.10 \pm 0.12$ & () $0.3 \pm 0.03$ & $0.17 \pm 0.15$ \\
\hline
\end{tabular}

Table A-3. PCB concentrations ( $\mathrm{PCB}$ ) in Hinds Creek reference site fish

\begin{tabular}{lcc}
\hline T'ype of GC Analysis & Species & $\sum \mathrm{PCB}(\mu \mathrm{g} / \mathrm{g})$ \\
\hline Capillary column & Carp & $0.04^{\mathrm{a}}$ \\
& Sunfish & $<0.02$ \\
& Carp & $<.\left(04^{\mathrm{a}}\right.$ \\
Palcked column & Sunfish & $0 .(22,0.06$ \\
& & $0.04 \pm 0.0\left(5^{\mathrm{b}}\right.$
\end{tabular}

"Hinds Creek simples from a different study annalyzed on the same dily.

b) mean $\pm \mathrm{SD}, \mathrm{n}=7$. 
Appendix B

DETAILED RESULTS OF PCB ANALYSES 


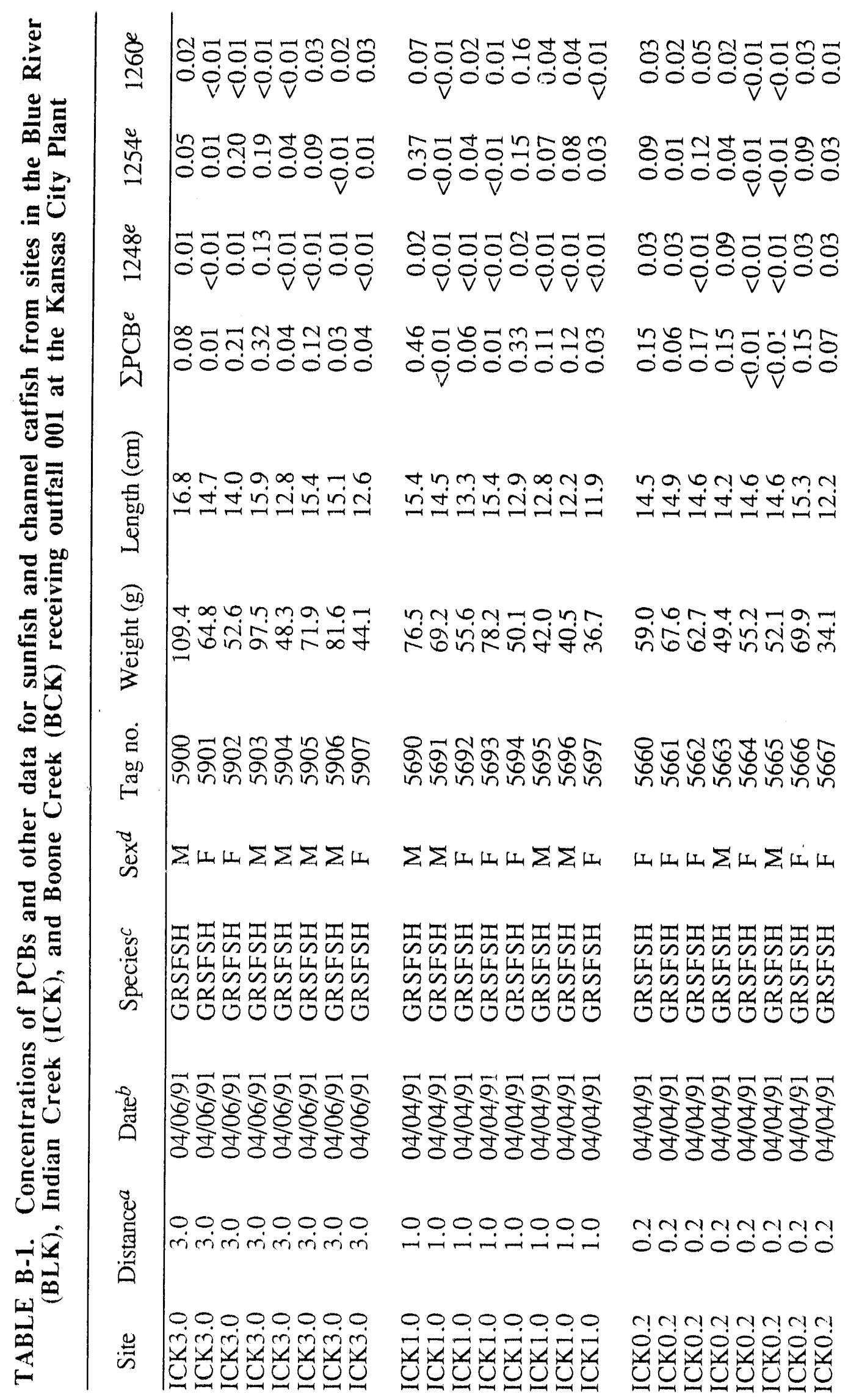

B-3 







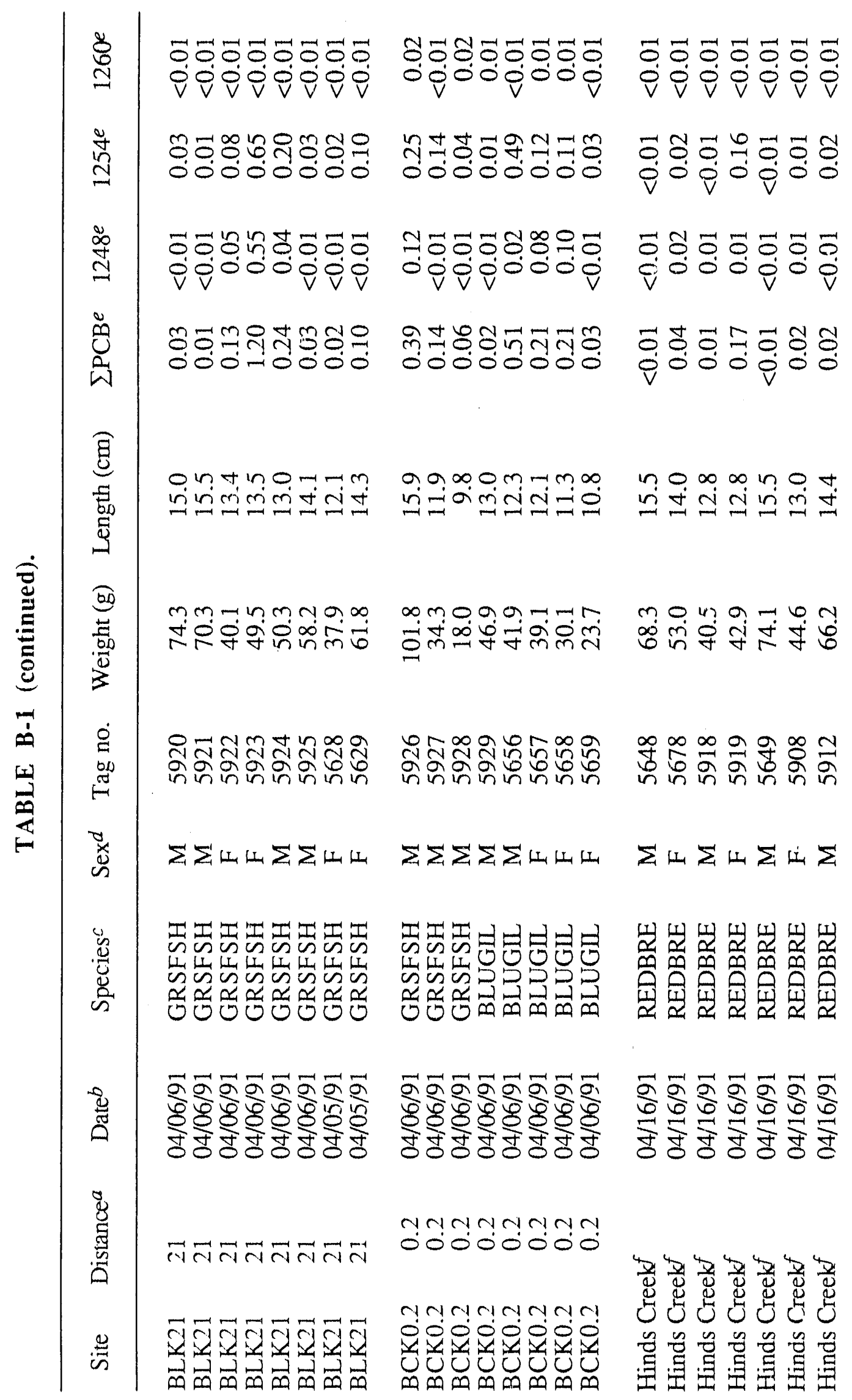

B-5 


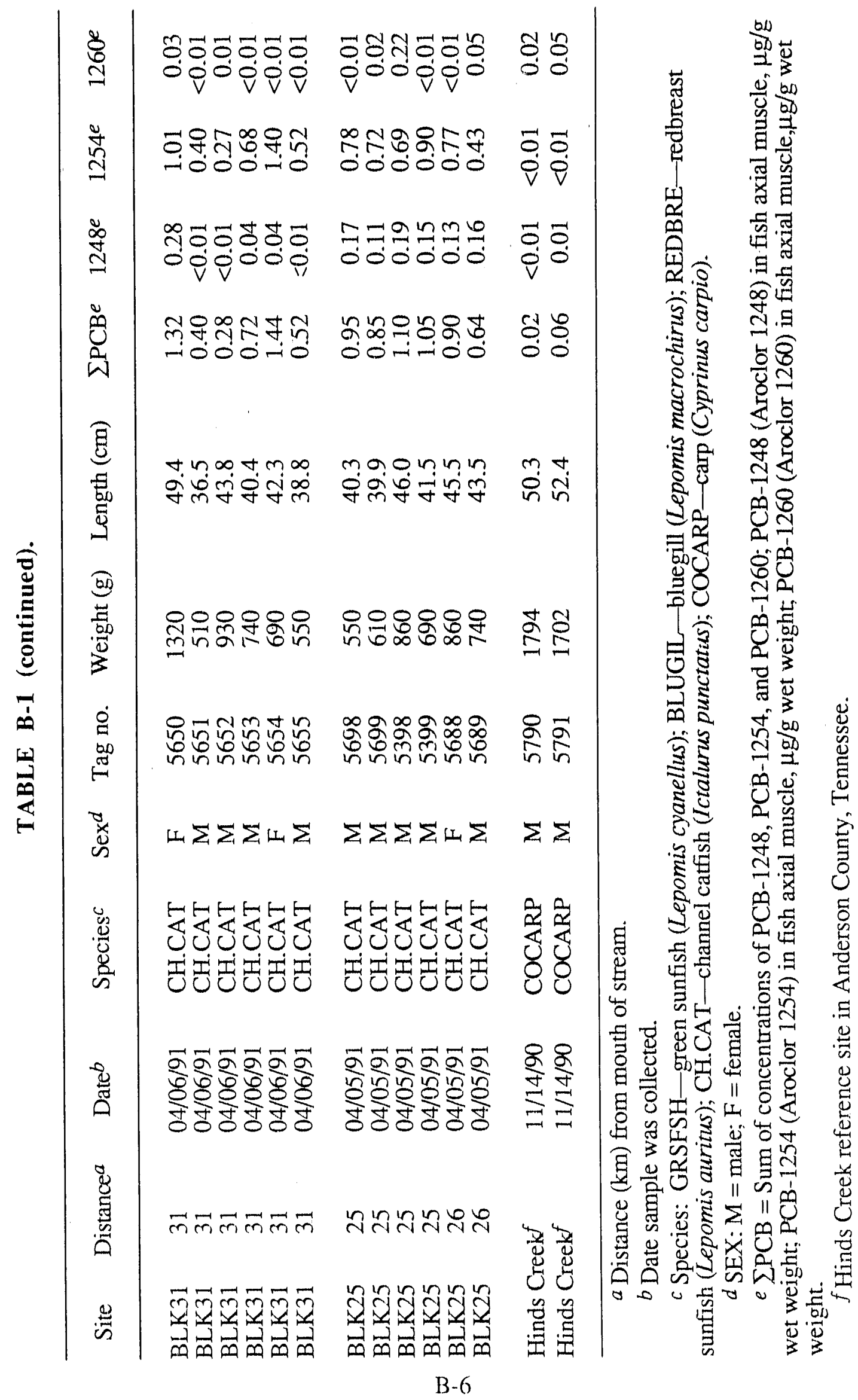


Appendix C

REPORT OF NEGATIVE ION CHEMICAL IONIZATION MASS SPECTROMETRY OF BLUE RIVER CATFISH SAMPLES 
August 5, 1991

M. P. Maskarinec

GC/MS analysis of two extracts generated from sample 910619-065, and 910619.066 (catfish)

\section{Summary of experiments:}

Aliquot of the extracts generated from samples 910619-065 and 910619-066 was evaporated to approximately $1 / 10$ of its original volume and subjected to GC/MS analysis. The analysis was performed on a Hewlett-Packard 5895 GC/MS in negative ion chemical ionization (NICI) mode. A capillary DB-5 column (30 m x $0.25 \mathrm{~mm} \mathrm{ID,} 0.25$ um film thickness) was used with a two-stage temperature program as the following: oven temperature was (1) held at $130^{\circ} \mathrm{C}$ for $1 \mathrm{~min}$, then increased to $180^{\circ} \mathrm{C}$ at $5^{\circ} \mathrm{C} / \mathrm{min}$; (2) increased to $250^{\circ} \mathrm{C}$ at $2^{\circ} \mathrm{C} / \mathrm{min}$, and held for $18 \mathrm{~min}$. Both injector and transfer line temperatures were set at $290^{\circ} \mathrm{C}$. The split/splitless injection port was held in splitless mode for $1 \mathrm{~min}$ after injection. NICI spectral analysis of eluate was carried out with methane as reagent gas. The flow rate of methane was regulated to maintain a source pressure of 0.45 torr. The electron energy was set at $200 \mathrm{eV}$, the emission current at $300 \mathrm{ua}$, and the source temperature at $100^{\circ} \mathrm{C}$.

\section{Summary of findings:}

As requested, results obtained from GC/NICI analysis was used to confirm the presence of polychlorinated biphenyls (PCB) in both extracts. Since PCB components were found at a trace level and often obscured by many overly abundant non-PCB components, the selective ion display was used to detect the PCB components. Furthermore, because multiple PCB components were detected in the extracts, the extracts may contain Aroclors. To confirm this, the selective ion display was used again to measure the ion abundances of the prominent ions in the chlorine clusters for eight PCB homologs $\left(\mathrm{Cl}_{2}-\mathrm{Cl}_{9}\right)$ within the $\mathrm{PCB}$ retention time window. Using these ion abundance measurements, classification of Aroclor was carried out by a computer program "AROCLASS.BAS" developed in this section. Results confirmed that both extracts contain Aroclor 1248 (see the following table).

C. Y. Ma, Analytical Chemistry (6-6691)

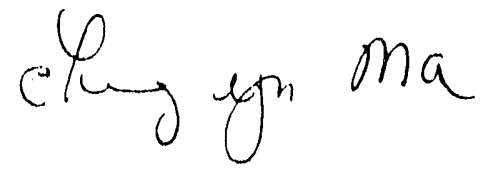

cc: M. V. Buchanan 


\section{Table Classification of Aroclors}

$\begin{array}{llll}\text { Sample } & \text { Aroclor Class } & \text { Linear Discriminant Function } & \text { Probability } \\ 910619-065 & & & \\ & & 187 & 1 \\ 1248 & 170 & 0 \\ 1232 & 165 & 0 \\ 1254 & 164 & 0 \\ 1221 & 164 & 0 \\ 1242 & 153 & 0 \\ 1260 & 69 & 0 \\ 1262 & & \\ 910619-066 & & 181 & 0.992 \\ & & 176 & 0.008 \\ 1248 & 171 & 0 \\ 1232 & 168 & 0 \\ 1221 & 162 & 0 \\ 1242 & 159 & 0 \\ 1254 & 62 & 0\end{array}$


Appendix D

DETAILS OF METHODS FOR TOXICITY TEST SAMPLE HANDLING 


\section{Appendix D}

\section{Detalls of the methods used for sample handlling}

The lec chest contains 9 color-coded 2-L poly bottles, 33 color-coded glass bottles, scrum stoppers and aluminum seals, a crimping tool to seal the glass bottles, a roll of duct lape, data shects, and a Ziplock bag. There are two extra nonlabelled glass bottles, as well.

1. First, please note that all of the bottles are color coded (exeept the two extra gless boltles). Make sure that they are sorted by these codes, such that each color code is associated wilh only one water-type (c.g., well $X=$ red, well $Y$ $=$ blue, and Outfall $=$ yellow). The three data shects are color-coded, as well, one per bottle set.

2. For each water type, lirst fill three poly bottles of the same color code as the glass bottles and cap them lightly. Then fill cach of the 11 glass botlles wlth freshly collected sample. Fach glass boltle should be filled to overflowing, then capped and sealed immediately as it is filled. To do this, place two of the teflon/rubber dlscs, blue slde towards the water sample, directly upon the bottle's mouth so as to exclude air bubbles. (Two are needed to ensure enough thickness so that the aluminum scal snugs the disks qulte firmly agalnst the glass!) Immediately place an aluminum seal over the discs and bottle's top, and crimp the scal with the tool. You can practioe crimplng a seal or two on one of the bottles before you do the first sample, if you like - there's a couple of spare bottles, dises and aluminum seals to allow that! If the bottle has becn properly scaled, no bubbles should be present in the sample. Take particular care to minimize exposure of the water to the alr as the sampic is collected and poured into the glass serum bottles, please!

3. A record must be kepl of the source of water in each color-coded set of bottles. The time of sample collection, and the name of the person collecting the sample should also be noted on the approprlate data sheet.

4. The bottled samples ( 3 poly plus 11 glass for each water type) should be placed in the lac chest. Sprinkle 5 lb of lec in, around, and upon the samples; seal the three completed data sheets in the enclosed Ziplock bag and enclose the sheets in the chest, $t(0)$, along with the crimper $t(0)$ and any miscellaneous extra items (e.g., aluminum seals, discs, duct lape, etc.) that were sent there. Then tape the chest shut and ship it (e.g., Federal Express or overnight mail). Thanks!

Ship to:

ATTENTION: Linda F. Wicker (6-8519)
Toxicology Laboratory, Bldg 1504, room 12
Environmental Sciences Division
Oak Ridge National Laboratory
PO Box 2008
Oak Ridge, TN 37831-6351


(SAMPLE) KANSAS CITY PLANT TOXICITY TESTS (ground/stream watcr samples)

\section{RED-CODED SAMPLES:}

Collection date:

Time of day:

Person collecting:

Sample description (e.g., well number/location, outfall number, etc.):

Any problems?

Information below to be filled in

by toxicology laboratory personnel

Received by:

Logged in registered book:

pp

Reception date:

Time:

Sample temperature upon reception:

Any problems? 
ORNL/TM-11932

\section{DISTRIBUTION}

1-5. T. L. Ashwood

6. B. A. Bervell

7. R. B. Clupp

8. R. B. Cring

9. C. W. Gehrs

10. S. G. Hildebrand

11. L. A. Kszos

12. J. M. Lour

13-17. M. J. Peterson
18-22. G. R. Southworth

23-27. A. J. Stewart

28. S. H. Stow

29. Central Research Library

30)-39. ESD Library

40)-41. Laboratory Records Dept.

42. Laboratory Records, ORNL-RC

43. ORNL Patent Section

44. ORNL Y.-12 Technical Library

45. D. W. Brown, D/922 SC-8, Allied-Signal, Inc., Kansas City Division, P. O. Box 419159, Kansas City, MO 64141-6159

46. J. F. Franklin, Bloedel Professor of Ecosystem Analysis, College of Forest Resources, University of Washington, Anderson Hall (AR-10), Seattle, WA 98195

47. G. M. Hornberger, Professor, Department of Environmental Sclences, University of Virginia, Charlottesville, VA 22903

48. G. Y. Jordy, Director, Office of Program Analysis, Office of Energy Research ER-30, G-226, U.S. Department of Energy, Washington, DC 20545

49. P. M. Kearl, Oak Ridge National Laboratory, Grand Junction Office, U.S. Department of Energy, P. O. Box 2567, Grand Junction, CO 81502

50. N. E. Korte, Oak Ridge National Laboratory, Grand Junction Office, U.S. Department of Energy, P. O. Box 2567, Grand Junction, CO 81502

51. C. A. Little, Oak Ridge National Laboratory, Grand Junction Office, U.S. Department of Energy, P. O. Box 2567, Grand Junction, CO 81502

52. R. H. Olsen, Vice President for Research, University of Michigan, Medical Science Building II, \#5605, 1301 East Catherine Street, Ann Arbor, MI $481(09-() 620$

53. A. Patrinos, Acting Director, Environmental Sciences Division, Office of Health and Environmental Research, ER-74, U.S. Department of Energy, Washington, DC 20585

54-63. M. E. Stites, D/922 SC-8, Allied-Signal, Inc, Kansas City Division, P. O. Box 419159, Kansas City, MO 64141-6159

64. F. J. Wobber, Environmental Sciences Division, Office of Health and Environmental Research, ER-74, U.S. Department of Energy, Washington, DC 20585

65. Office of Assistant Manager for Energy Research and Development, U.S. Department of Energy Oak Ridge Field Office, P.O. Box 2(k)1, Oak Ridge, TN $37831-86())$

66-75. Office of Scientific and Technical Information, P.O. Box 62, Oak Ridge, TN 37831 



1

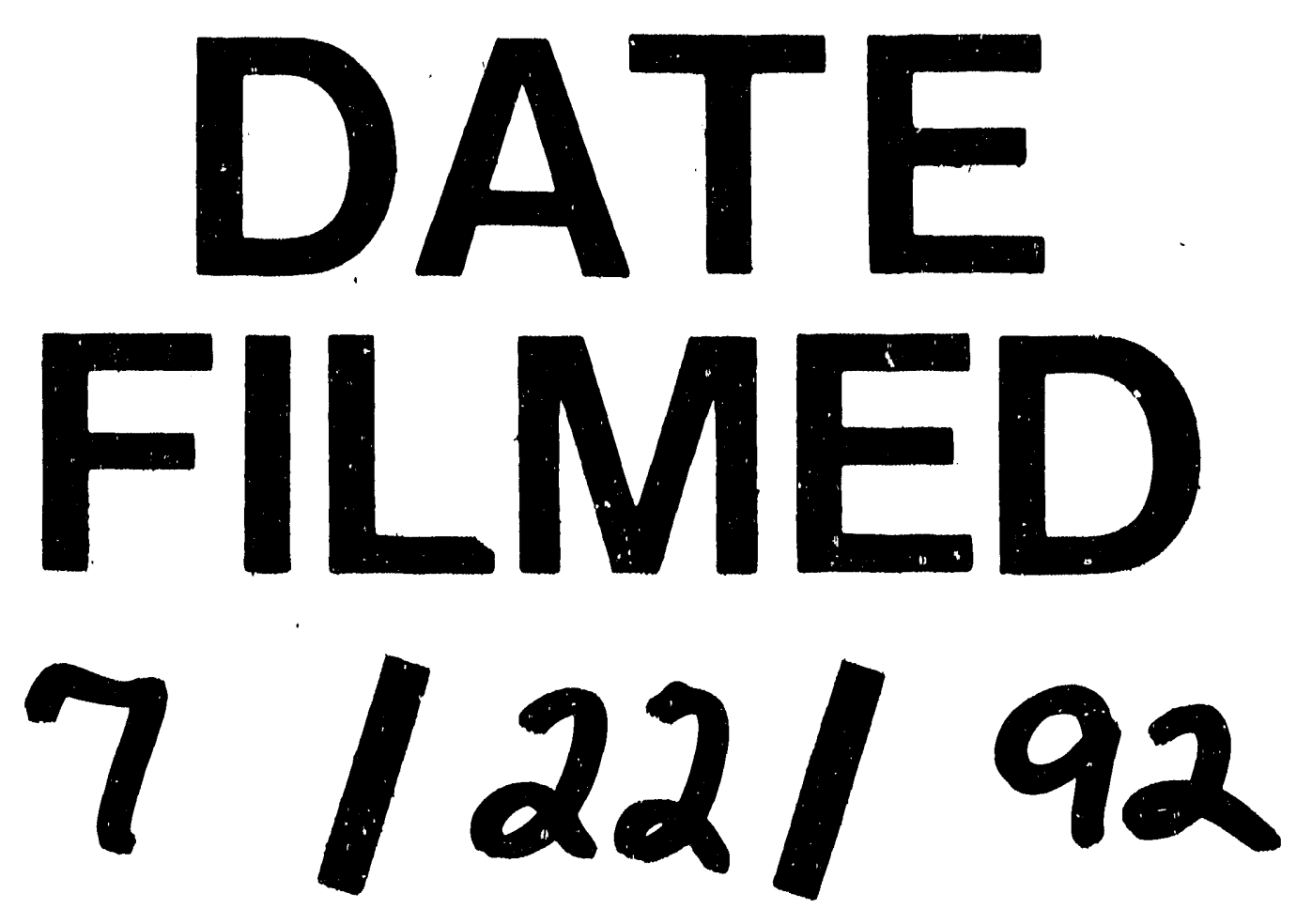


